\title{
Coastal upwelling and downwelling forcing of circulation in a semi-enclosed bay: Ria de Vigo
}

\author{
Barton, E.D. ${ }^{1}$, Largier, J.L. ${ }^{2}$, Torres, R. ${ }^{3}$, Sheridan, M. ${ }^{2,8}$, Trasviña, A. ${ }^{4}$, Souza, A., ${ }^{5}$ Pazos, \\ $\mathrm{Y}^{6}$, Valle-Levinson, A. ${ }^{7}$ \\ ${ }^{1}$ Instituto de Investigaciones Marinas CSIC, Vigo, Spain, barton@iim.csic.es \\ ${ }^{2}$ Bodega Marine Laboratory UC Davis, Bodega Bay, USA jlargier@ucdavis.edu \\ ${ }^{3}$ Plymouth Marine Laboratory, Plymouth, UK, rito@pml.ac.uk \\ ${ }^{4}$ CICESE, La Paz, Mexico, trasvi@ cicese.mx \\ ${ }^{5}$ Proudman Oceanographic Laboratory NOC, Liverpool, UK, ajso@ pol.ac.uk \\ ${ }^{6}$ INTECMAR, Vilagarcía de Arousa, Spain, ypazos@intecmar.org \\ ${ }^{7}$ University of Florida, Gainsville, USA, arnoldo@ufl.edu \\ ${ }^{8}$ Now at: Plymouth University, Plymouth, UK, megan.sheridan@plymouth.ac.uk
}

\begin{abstract}
$\underline{\text { Abstract }}$
Semi-enclosed bays in upwelling regions are exposed to forcing related to winds, currents and buoyancy over the shelf. The influence of this external forcing is moderated by factors such as connectivity to the open ocean, shelter by surrounding topography, dimensions of the bay, and freshwater outflows. Such bays, preferred locations for ports, mariculture, marine industry, recreational activities and coastal settlement, present a range of characteristics, understanding of which is necessary to their rational management. Observations in such a semi-enclosed bay, the Ria de Vigo in Spain, are used to characterize the influence of upwelling and downwelling pulses on its circulation. In this location, near the northern limit of the Iberian upwelling system, upwelling events dominate during a short summer season and downwelling events the rest of the year. The ria response to the external forcing is central to nutrient supply and resultant plankton productivity that supports its high level of cultured mussel production. Intensive field studies in September 2006 and June 2007 captured a downwelling event and an upwelling event, respectively. Data from eight current profiler moorings and boat-based MiniBat/ADCP surveys provided an unprecedented quasi-synoptic view of the distribution of water masses and circulation patterns in any ria. In the outer ria, circulation was dominated by the introduction of wind-driven alongshore flow from the external continental shelf through the ria entrances and its interaction with the topography. In the middle ria, circulation was primarily related to the upwelling/downwelling cycle, with a cool, salty and dense lower layer penetrating to the inner ria during upwelling over the shelf. A warmer, lower salinity and less dense surface layer of coastal waters flowed inward during downwelling. Without external forcing, the inner ria responded primarily to tides and buoyancy changes related to land runoff. Under both upwelling and downwelling conditions, the flushing of the ria involved shelf responses to wind pulses. Their persistence for a few days was sufficient to allow waters from the continental shelf to penetrate the innermost ria. Longer term observations supported by numerical modeling are required to confirm the generality of such flushing events in the ria and determine their typical frequency, while comparative studies should explore how these scenarios fit into the range of conditions experienced in other semi-enclosed bays.
\end{abstract}




\section{Introduction}

Topographically sheltered waters in upwelling regions exhibit high levels of productivity due to in situ primary production associated with the introduction of nutrient-rich waters. The character of these sheltered waters is determined by their juxtaposition with the open coastal waters in which winds drive upwelling. Tidal and sub-tidal exchanges both play a role, with the importance of each depending on local forcing and topography. In the case of estuaries, river input of freshwater contributes to the baroclinic exchange. Upwelling regions are characterised by Mediterranean climates where this freshwater inflow is typically a secondorder effect during the upwelling season, but nevertheless may be sporadically important, especially in the wet winter season.

The Ria de Vigo is longer and narrower than many open bays in upwelling areas, e.g., Monterey Bay in California, False Bay in South Africa, Antofagasta Bay in Chile, and Todos Santos Bay in Mexico. It resembles them however in that its primary hydrographic and circulation features are determined by the extension of wind-driven flow on the external continental shelf throughout the bay. On the other hand, the ria is broader, deeper and more open than most enclosed bays in upwelling areas (e.g., Tomales Bay and San Diego Bay in California, Saldanha-Langebaan Bay in South Africa, San Quintin Bay in Mexico, and Concepcion Bay in Chile). In these more enclosed bays, tidal exchange processes play an important role but ocean-bay density differences are also important and coherent baroclinic exchange flow is observed at times. In all upwelling bays that are large enough to retain water for a few days or more, stratification is important due to strong surface warming of cold upwelled waters. The many realizations of the interaction of winds and tides with 
stratification, topography and baroclinic forcing lead to multiple variations on the theme of "upwelling bay". Here, we particularly examine the transient response of the Ria de Vigo during upwelling and downwelling wind events, providing new insights to the circulation and hydrography of upwelling bays in general.

The Ria de Vigo at $42.2^{\circ} \mathrm{N}$ is one of the Rias Baixas, four elongated coastal indentations in Galicia, NW Spain, near the northern limit of the Iberian upwelling ecosystem (Figure 1). The ria is mesotidal and dominated mainly by semidiurnal tides (Álvarez et al., 2005; Cerralbo et al., 2013). Here the high level of productivity that characterizes sheltered waters in upwelling regions is reflected in one of the most economically important mariculture industries in Europe (Blanton et al., 1987; Figueiras et al., 2002). The continental shelf outside the ria is characterized by both upwelling and downwelling events year-round, with upwelling events dominating during the summer and downwelling events dominating at other times (Blanton et al., 1984). During upwelling winds over the shelf, sub-surface central water intrudes as a lower layer into these rias, and during downwelling winds this colder lower layer disappears from the ria as oceanic surface waters flow into the ria (Mourinho and Fraga, 1982; Rosón et al., 1997, Gilcoto et al. 2001; Piedracoba et al., 2005). During wet periods, enhanced buoyancy inputs from rivers further south, such as the Miño and Duero, are responsible for a near-shore, poleward flow known as the Western Iberian Buoyant Plume (Peliz et al., 2002; Santos et al., 2004). The buoyant plume is typically seen under northward winds as a wedge of fresher (typically $\mathrm{S}<35.6$ ) water banked up against the coast. Southward wind disperses the plume offshore in a thin layer, but it reforms quickly following return to northward wind. It is characteristically warm at the end of summer because of warming in the watershed and estuaries. 
Prior studies in the Ria de Vigo have primarily addressed biogeochemistry, and in particular nutrients and phytoplankton, including blooms of toxic alga that impact negatively the mariculture (González Vilas et al., 2014). In addition, estimates of exchange and retention of ria waters have been calculated from weekly hydrography through use of box models (Prego and Fraga, 1992). The estuarine nature of the ria was explored by Taboada et al. (1998), who modelled the seasonally varying influence of river inflow in the absence of external forcing. Torres López et al. (2001) and Souto et al. (2003) demonstrated the importance of external forcing on the ria in reversing the sense of the two-layer flow regime during upwelling and downwelling situations simulated with numerical models. The latter also found inflow through the northern mouth and outflow through the southern mouth during upwelling conditions and the opposite during downwelling conditions, similar to the box model results of Gilcoto et al $(2001 ; 2007)$.

The aims of the present study were (1) to determine the path and nature of the through-flow in the outer ria, (2) to examine the setup of the two layer circulation and follow the propagation of upwelled and downwelled waters through the ria, and (3) to determine the rate of flushing and related vertical velocities in the ria, under conditions of both upwelling and downwelling. The detailed observations provide a high-resolution view of the ocean-ria exchange processes and reveal important asymmetries in the upwelling and downwelling responses. Without high-frequency data, one cannot fully describe or understand the dynamics of exchange processes, nor how ria-ocean exchange compares with the exchange between shelf and sheltered waters in other upwelling regions. 


\section{Methods}

\subsection{Study area}

The Ria de Vigo (Figure 1) has a surface area of $176 \mathrm{~km}^{2}$, a length of $21 \mathrm{~km}$ from Islas Cies to the Rande strait (roughly Line 7a), a volume of $3.12 \mathrm{~km}^{3}$, and is oriented roughly along $70^{\circ}$. The broad outer ria ( $15 \mathrm{~km}$ wide) is connected to the Atlantic by two mouths separated by the Cies. Both mouths are narrow, with distances of $\sim 2 \mathrm{~km}$ and $\sim 3 \mathrm{~km}$ between $10 \mathrm{~m}$ isobaths in the northern and southern (at $\sim 8.89^{\circ} \mathrm{W}$ ) mouths, respectively. The "outer ria" represents the broad open waters west of Bouzas $\left(\sim 8.79^{\circ} \mathrm{W}\right)$, the "middle ria" consists of the waters between $8.79^{\circ} \mathrm{W}$ and $\sim 8.71^{\circ} \mathrm{W}$, and the "inner ria" describes the narrow and shallow waters further east. The outer ria contains an extensive area 30-40 m deep that drops steeply to a $60 \mathrm{~m}$ deep channel in the southern mouth and shoals toward the $25 \mathrm{~m}$ deep sill in the northern mouth. The middle ria narrows to $\sim 4 \mathrm{~km}$, with distance between $10 \mathrm{~m}$ isobaths $\sim 2 \mathrm{~km}$, but the central channel remains deeper than $30 \mathrm{~m}$, with some basins $>40 \mathrm{~m}$. The channel shoals toward the inner ria, which is mostly much narrower (less than $2 \mathrm{~km}$ ) and reaches a minimum of $10 \mathrm{~m}$ before deepening slightly through the narrows at Rande, $\sim 8.66^{\circ} \mathrm{W}$. Most freshwater input enters the shallow (mean $7 \mathrm{~m}$ ) Ensenada de San Simon inland of the narrows, where it is tidally mixed with ria waters before passing through the strait into the interior ria.

\subsection{The Field Study}

Studies were carried out in September 2006 and June 2007 to capture conditions during the demise and inception, respectively, of the upwelling season. In the first period, bottom 
mounted acoustic Doppler current profilers were deployed at A1-7 (Figure 1 and Table 1), while in the second these were redeployed along with one additional ADCP on the southern flank of the southern entrance (A8). Thus, the inner ria is represented by A1, the middle ria is represented by $\mathrm{A} 4$, and the outer ria is represented by $\mathrm{A} 2 / 3 / 5 / 6 / 7 / 8$. Current profilers recorded for periods including the 5-day intensive period of ship-board sampling. At positions A2 and 3, thermistor moorings (Onset TidBit) were deployed, with near surface and bottom temperature-salinity loggers (SeaBird SBE37). During the second study, additional thermistor moorings T1/4/5/7 were deployed at the positions shown in Figure 1. Sampling was at 20-minute intervals at A7 during 2006, and at 10 minutes or less at all other instruments in both studies.

During the 5-day intensive periods, sampling was carried out from the R/V Mytilus on the lines shown in Figure 1. The entire grid was sampled at the start and end of the intensive period of the first study and midway through the second, while on other days, particular transects were sampled repeatedly over the semi-diurnal tidal cycle. An Applied MicroSystems CTD, plus Wetlabs fluorometer and OBS turbidometer, mounted on a towed Guildline MiniBat undulator was used to enable rapid sampling with high spatial resolution. Towing at about 5 knots provided vertical profiles roughly every $150 \mathrm{~m}$. The shipboard RD Instruments ADCP simultaneously monitored currents with a similar resolution, so that a coherent suite of hydrographic and current observations was gathered. Additionally CTD/Rosette profiles were made on most days at the middle and ends of the sampling lines shown in Figure 1. These provided hydrographic observations with a SeaBird SBE9 in the deepest layers not reached by the MiniBat and captured water samples for biogeochemical analyses, some results of which are reported elsewhere (Romera-Castillo et al., 2011; 
Seeyave et al.. 2013). The ship also sampled a variety of underway parameters at 1-minute intervals, including temperature and salinity at $2.5 \mathrm{~m}$ depth, air temperature, and wind velocity. A smaller second vessel, Arao, sampled the inner and middle ria with a SeaBird SBE25 for temperature, conductivity, turbidity and transmittance.

Underway ADCP data were processed with the University of Hawaii CODAS system (Firing et al., 1995). After correction for heading errors, ADCP data were averaged over intervals of 1 minute in time and $1 \mathrm{~m}$ depth to provide high spatial resolution within the narrow ria.

Complementary data included wind records from Bouzas in the middle ria, from the Cies islands at the mouth of the ria, and from the Silleiro buoy, $10 \mathrm{~km}$ offshore of the islands, and sea level at the port of Vigo, as indicated in Figure 1. The winds were obtained at hourly or more frequent intervals. Winds at the Silleiro buoy (exhibiting similar time-dependence as winds at Cies) are used as the principal indicator of upwelling and downwelling over the shelf because the Cies series was interrupted by a gap of 12 days in 2007 . The Bouzas wind record in 2006 proved unreliable, but good data were obtained in 2007. The sea level data from the Vigo tide gauge were provided as de-tided daily values by Puertos del Estado. These were corrected for the inverse barometer effect with atmospheric pressure from Vigo airport and then de-meaned over the period around the surveys.

The wind and ADCP time series were edited for outliers, had small gaps filled by interpolation with a cubic spline, and those sampled more often than once per hour were averaged to 1-hour intervals. A Cosine-Lanczos filter with half-power point at $40 \mathrm{~h}$ was then run over the hourly series to eliminate variability with periods less than $40 \mathrm{~h}$. Currents were 
rotated into "inward" and "across" ria components, whose orientation varied between sites. The axis directions were determined by examination of the principal axes of the variability at each site and the orientation of the local bathymetry. All CTD sensors were calibrated prior to the first study and after the second and were checked by field calibrations for salinity and by intercomparisons in simultaneous casts adjacent to moored sensors to ensure a coherent data set.

3. Results

3.1 Downwelling

The September 2006 study captured a downwelling event during the transition from summer to winter conditions. Winds turned irregularly from their summer southward predominance to northward several weeks before the intensive sampling period 25 Sept-1 October (Figure 2). Short pulses of weak, southward wind continued to appear at 5-7 day intervals. Outside the ria, AVISO altimetry and AVHRR sea surface temperature maps (not shown) indicated the development of warm, poleward flow along the continental slope and shelf throughout the period. Mid-channel bottom temperature at A4, in the middle ria, reflected wind forcing with a time lag of $\sim 2$ days (Figure 2). Within a day of the re-establishment of northward winds on 27 September, flow at A4 changed from near zero throughout the column to a two-layer system strongest (outflow $>15 \mathrm{~cm} \mathrm{~s}^{-1}$ ) on 30 September with inflow above $15 \mathrm{~m}$ depth. The presumably fast near-surface inflow in the uppermost bins was missed by the ADCP. During brief southward winds on 3-5 October, the two-layer flow reversed temporarily. De-tided, atmospherically corrected sea level in the port of Vigo tended to rise with the onset of northward wind and to decrease with the weakening of northward wind. 
As downwelling-favorable wind was established on 27 September and sea level rose, surface temperature was increasing in both outer (at A3) and inner (near A1) ria (Figure 3a and b). Bottom temperatures responded more slowly. Warming was seen first at A2 and A3 (outer ria) at $20 \mathrm{~m}$ depth from 28 September, but was not evident at $40 \mathrm{~m}$ at A4 in middle ria until a day later. Warming of the bottom layer at A7 in the southern mouth was delayed another day. The bottom water at A5 in the outer ria responded last, warming irregularly, while always remaining the coldest water in the ria. The highest temperatures were near-surface at A1, inner ria, where warming was simultaneous with that at A2 and A3. Within 4 days of the onset of downwelling, temperature was $18-18.5^{\circ} \mathrm{C}$ throughout the inner and middle ria.

During the poleward wind event, decreasing salinity and increasing temperature were seen at all depths at moorings A2 and A3 in the outer ria (Figure 3c and d). Upper layer temperatures, e.g., at $2 \mathrm{~m}$ depth at A2, started to increase with the wind onset of 27 September and completed the transition to near-constant warmer conditions after 2 days. The warming occurred increasingly later deeper in the water column; the response at $20 \mathrm{~m}$ took place almost two days later than near surface. Temperature structure at A2 and A3 changed from initially almost homogeneous to stratified during the transition to a warmer, again homogeneous final state. The initial surface inflow warmed the upper layers rapidly, but at depth warming took longer to establish and spread from the inner to outer ria.

Salinity at A2 and A3 (Figure 3c) decreased gradually throughout the 5-day wind event, and was consistently lower on the south shore (A2) and at depth. In the innermost ria, near A1, river outflow was indicated by significantly lower surface salinity at the start of the event. 
Because the surface water flowing in from the ocean, though fresh compared to most of the ria, was saltier than the river-influenced waters, salinity near A1 increased during the event. Salinities near A1 approached but did not reach the values seen in the outer ria, before decreasing again as inflow from the outer ria weakened.

Currents at moorings A6 and A7 in the mouths of the ria varied strongly in concert with these hydrographic changes (Figure 4). Inflow at A7 accelerated from near zero at all depths on 26 September during the following days of northward wind while the inflowing layer thickness deepened to include the entire water column at the mooring site $(33 \mathrm{~m})$. Inflow ceased abruptly on 3 October as the wind turned weakly equatorward, remaining weak until the commencement of the next interval of northward wind 3 days later. The central mooring A5 recorded flow close to zero throughout the period (not shown). The weak flow in the northern entrance (A6) on 26 September, accelerated during the following days to peak at $>20 \mathrm{~cm} \mathrm{~s}^{-1}$ outflow simultaneous with the maximum inflow at A7 (Figure 4) and strongest two-layer flow at A4 (Figure 2) on 30 September. The flow was nearly barotropic through the measured water column at A6, but baroclinic at A7. Neither ADCP measured currents above $7 \mathrm{~m}$ depth. On 3 October the outflow returned to near zero with the wind relaxation. Thus, during the downwelling wind event, inflow was observed in the upper layers through the southern mouth while outflow was observed at all depths through the shallower northern mouth.

Sections across the outer ria (Line 5 in Figure 1) at the start and end of the intensive period (Figure 5) were consistent with entry of coastal water from the external continental shelf through the southern mouth. Temperature increased by up to $1^{\circ} \mathrm{C}$ while salinity decreased by 
0.4- 0.5 between the 26 and 30 Sept sections. Although the inward component (towards $70^{\circ}$ ) of shipboard ADCP currents was virtually null during the weak southward wind of $26 \mathrm{Sept}$, signs of previous inflow were evident in the lower salinity $(<35.6)$ water banked against the southern shore. In the later section, a clearly defined inflow advected higher temperature and lower salinity waters above $30 \mathrm{~m}$ along the southern shore of the ria, while outflow of ria waters took place along the northern shore and at depth. Salinity decreased overall between the sections, but the north-south contrast in salinity (and density) was maintained between the inflowing fresher water mass and the outflow further north. The intensification of the circulation was reflected in the changing slope of isotherms (and isopycnals) from almost horizontal during the earlier section to strongly up-warped in mid-channel in the later. The 30 Sept flow structure had two layers in the southern mouth, inflowing above $30 \mathrm{~m}$ and weakly outflowing beneath, and vertically uniform outflow in the north. Transports in and out of the ria were estimated from the ship section of 30 Sept as $14.5 \times 10^{3} \mathrm{~m}^{3} \mathrm{~s}^{-1}$ and $13.9 \times 10^{3} \mathrm{~m}^{3}$ $\mathrm{s}^{-1}$, respectively. The difference was not significant, given that it was only a tenth of the surface inflow extrapolated conservatively by assuming constant velocity between first ADCP bin and surface. The ship currents correspond well with the structure seen at the nearby moorings given the along channel separation (Figures 5 and 4). The A7 mooring, located on the north slope of the southern channel, did not measure the outflow below $30 \mathrm{~m}$ observed by the ship ADCP in deeper mid-channel. The near-zero flows observed at A5 arose from the mooring's location on the boundary between in- and outflow.

On 28 September, as the wind event was developing, Line 3 across the middle ria was sampled 28 times over the semi-diurnal cycle. The tidally-averaged sections (Figure 6) contain all data from Minibat, CTD casts in mid-channel, ship $2.5 \mathrm{~m}$ depth underway 
sampling and data from mooring sites A2 and A3.The currents are projected onto axes along (toward $70^{\circ}$ ) and across (toward $160^{\circ}$ ) the channel. The inward component indicated a 2-layer circulation with inflow above and outflow beneath an interface tilted up toward the north. The cores of maximum inflow and outflow were offset laterally, consistent with Coriolis effects. The transverse component indicated northwestward flow except near shore, strongest in the uppermost layers in mid-channel. The lower layer outward transport was $2.7 \times 10^{3} \mathrm{~m}^{3} \mathrm{~s}^{-1}$ while the upper layer inflow was estimated at $1.3 \times 10^{3} \mathrm{~m}^{3} \mathrm{~s}^{-1}$. The latter is less reliable because of extrapolation with a constant velocity layer assumption in the unsampled nearsurface zone. The lowest salinity was found above $10 \mathrm{~m}$ on the southern side, and the halocline (and pycnocline) was tilted up to the north, as expected. The temporal trends over the semi-diurnal cycle indicated decreasing salinity and density, and increasing temperature.

The two-layer regime was seen clearly in the along-ria section 7a of 29 September between moorings A4 and A5 (Figure 7), which is the mean of 8 transects made over 11 hours, almost a complete tidal cycle. East of $8.82^{\circ} \mathrm{W}$ the transect follows the central channel of the ria, but in the west ascends slightly onto the flatter area around A5 (Figure 1). The coolest, saltiest and densest water was isolated in the bottom $15 \mathrm{~m}$ over this flatter zone, while the middle ria was warmer. A column of less salty and more weakly stratified water was evident between 8.79 and $8.84^{\circ} \mathrm{W}$. The ship ADCP velocity components, rotated into inward (along channel toward $70^{\circ}$ ) and across (toward $160^{\circ}$ ) indicate flow into the ria was taking place along channel above roughly $15 \mathrm{~m}$, as seen at A4 (Figure 2c) on the same date, though the shallowest levels were not sampled. Stronger outflow took place at deeper levels, reaching 20 $\mathrm{cm} \mathrm{s}^{-1}$ near the bottom, but weakened near A5 behind the islands. Weak northward flow occurred throughout the water column in association with the lower salinity water in mid- 
section.

In the interior ria, an estuary-like circulation at A1, which was strongest during the brief southward wind episode of 26 September, reversed to a downwelling circulation (not shown) on 29 and 30 September. Thus it is clear that the two-layer downwelling flow regime of the outer and middle ria at times penetrated the inner ria at least as far as A1.

Maps of salinity at $5 \mathrm{~m}$ from 26 and 30 September illustrate the complete replacement of the water mass of the ria, which freshened by $\sim 0.4$ in salinity (Figure 8 ), and warmed by $1^{\circ} \mathrm{C}$. The salinity distributions were suggestive of re-circulation across the middle ria near $8.8^{\circ} \mathrm{W}$ of the less saline water that entered along the southern coast. De-tided moored ADCP currents at mid-day on both days, overlaid on the maps show, nevertheless, that during the relaxed winds on 26 September there was a weak outflow near surface $(5-7.5 \mathrm{~m})$ almost everywhere. Outward flow was strongest in the inner ria at A1, where estuary-like circulation was important. Flow in the lower layer ( $\sim 5 \mathrm{~m}$ above bottom) was also weak and directed outward almost everywhere except in the inner ria. This estuarine cell did not extend as far as the middle ria A4. In contrast, the near surface layer currents on 30 September flowed strongly inward from the southern mouth to the interior. In the northern entrance, flow was strongly outward. At A2 flow was directed northward across the ria, consistent with re-circulation of the entering water mass and the outflow through the northern mouth. Near bottom currents were consistently outward, strongest at A4 and in the north entrance. The two-layer circulation extended from the southern mouth to the inner ria at A1. At moorings A2 and A3, the bottom flow was weaker but again consistent with cross-ria re-circulation. A strong deep outflow was observed in the channel between these moorings by ship ADCP. On both days 
flow at all depths at A5 in the centre of the outer ria was weak, indicating it was a quiescent area as indicated by the slow temperature changes observed there.

\subsection{Upwelling}

The June 2007 study captured an upwelling event. Conditions outside the ria, revealed by the few available cloud-free satellite SST images (not shown), indicated no upwelling under the preceding northward wind conditions. Equatorward winds over the shelf commenced on 22 June (Figure 9a) and after a brief relaxation two days later, they strengthened during the intensive observation period, before weakening on 28 June and reverting on 29 June to weakly northward for a few days. The onset of the upwelling was seen in the middle ria as a rapid drop of $4^{\circ} \mathrm{C}$ in bottom temperature at $\mathrm{A} 4$ (Figure $9 \mathrm{~b}$ ), only about $24 \mathrm{~h}$ after the start of equatorward wind. Atmospherically adjusted sea level increased during the initial period of northward winds, but started to drop as soon as winds weakened. It had fallen $20 \mathrm{~cm}$ in total by the time of maximum southward winds on 28 June, but rose quickly during the following relaxation, only to drop further during the succeeding southward wind pulse. The along-ria component of currents at A4 (Figure 9c) followed closely the changes in wind and sea level. At all observed levels ( $>8 \mathrm{~m}$ below surface) inflow accompanied falling sea level and southward winds, while outflow coincided with rising sea level and more northward winds. The pulse of inflow, $>10 \mathrm{~cm} \mathrm{~s}^{-1}$ at $35 \mathrm{~m}$ on 23 June, which coincided with the first intrusion of cold bottom water, was followed by weakening inflow at depth and outflow above $25 \mathrm{~m}$ during the brief wind relaxation of the following day. Inflow was re-established within hours throughout the water column as favorable winds returned, but weakened again to zero after 27 June, when adjusted sea level reached a minimum but wind was strongest. Layers above 8 
$\mathrm{m}$, where strong outflow might be expected during deep inflow, were not sampled by the ADCP.

The entry of the colder bottom water and its spread through the ria was captured in part by the ADCP and thermistor moorings (Figure 10a and b), although the cold event started before outer moorings A5, A7 and A8 were deployed. On 23 June bottom temperature in the northern mouth at $\mathrm{A} 6$ dropped abruptly from 17 to $15^{\circ} \mathrm{C}$ as the wind became southward, recovered briefly, then dropped sharply again to around $15^{\circ} \mathrm{C}$, before continuing to fall more gradually through $24-25$ June to near $13^{\circ} \mathrm{C}$. Remarkably, bottom temperature at A4 in the middle ria decreased simultaneously with that at A6 late on 23 June. The decrease at A4, rapid at first, slowed and stopped when temperature reached $\sim 12.8^{\circ} \mathrm{C}$ by 26 June. The width of the front passing A4 is estimated at $7.6 \mathrm{~km}$ from the bottom cooling of $3.5^{\circ} \mathrm{C}$ and continuous inflow at average speed $11.0 \mathrm{~cm} \mathrm{~s}^{-1}$ over 19 hours.

At the shallower bottom depth of $20 \mathrm{~m}$ at $\mathrm{A} 1$, in the inner ria, the temperature drop occurred two days after $\mathrm{A} 4$ to reach a near constant temperature just above $13^{\circ} \mathrm{C}$ after 2 days. The change at A1 was tracked almost exactly by $20 \mathrm{~m}$ deep thermistors at nearby sites T1 (not shown) and T7. Moreover, bottom temperatures near $20 \mathrm{~m}$ at A3 (and A2, not shown) dropped almost simultaneously with those at A1 despite their position on the border between outer and middle ria. This suggests that the colder water introduced rapidly along the bottom near $40 \mathrm{~m}$ depth into the middle ria needed two days to become incorporated into the shallower levels around $20 \mathrm{~m}$. In the shallower bottom depth of $12 \mathrm{~m}$ at T4, midway between A4 and A2 on the south bank of the ria, the main temperature decrease was delayed by another 2 days, similar to the signal at $12 \mathrm{~m}$ at A2 (Figure 10d), whereas at $20 \mathrm{~m}$ depth at T5 
(not shown) on the opposite shore temperatures followed closely bottom (20 m) temperatures at $\mathrm{A} 1, \mathrm{~A} 2$ and $\mathrm{A} 3$.

At A2 the water column was initially almost uniform in both temperature and salinity, but bottom temperature started to drop slightly as soon as wind commenced to blow southward on 21 June (Figure 10c and d). Bottom temperature continued to decrease unevenly until late 25 June when the major decrease occurred. During the same period surface temperature increased slightly as warmer water from the inner ria was flushed outward. After 25 June, surface temperatures started to decrease as mixing or upwelling of the cooler, deeper water introduced along the central channel became evident. The cooling was progressively delayed with height in the water column, so that it occurred about 2 days later at surface than at bottom. Evolution of temperature followed the same pattern at A3 (not shown) on the north shore of the ria. The irregular decrease of surface salinity at both A2 and A3 during the first days after upwelling wind onset indicated outflow of the patchy, low salinity river-influenced waters of the interior. After 26 June surface salinities commenced to increase, and surface temperature to decrease with the arrival of upwelled oceanic water. In contrast, bottom salinities increased gradually from the start of the upwelling event, as influence of the deeper oceanic waters was felt.

Equatorward wind was already established by the start of the outer mooring observations on 25 June. By this time, water was flowing in through the northern mouth at A6, continuing across A5 in the central flatter area, and flowing out through A7 on the northern slope of the southern mouth (Figure 11). Maximum southward currents coincided with strongest equatorward winds on 27 June. Flow at A7 weakened with depth to zero at $30 \mathrm{~m}$, but the 
mooring was positioned too shallow to detect the main inflow of upwelled water at deeper levels. The subsequent weakening and turn to northward of the wind on 30 June was reflected in the currents at all three moorings, though the strongest northward flow appeared in the northern mouth. From 4 July on, a resurgence of equatorward wind produced another event of southward flow through the outer ria.

A central CTD section, Line 7b in Figure 1, showed the ria on 18 June was warm and relatively unstratified in temperature $\left(17.25-18.25^{\circ} \mathrm{C}\right)$ during the northward winds prior to the event (Figure 12). Salinities were relatively low $(\mathrm{S}<34.5)$ and decreased toward the inner ria, as a result of retention of river outflow during the preceding downwelling. By the second day of the intensive study on 26 June all waters below $10 \mathrm{~m}$ depth had been replaced by colder (13.3-17. $\left.0^{\circ} \mathrm{C}\right)$, more saline $(35.0-35.7)$ waters that introduced strong stratification. The section, an average of six Minibat transects over a semi-diurnal cycle, revealed lowest salinity waters $(<33)$ in a thin surface layer bounded by a thermocline/pycnocline at $\sim 5 \mathrm{~m}$ depth, above the shallowest available ADCP observations. A secondary thermocline/pycnocline, located near $15 \mathrm{~m}$ in the inner and middle ria on 26 June, capped the higher salinity $(>35.5)$ and cooler $\left(<13.5^{\circ} \mathrm{C}\right)$ near-bottom waters. Isotherms (and isopycnals) above $10 \mathrm{~m}$ sloped upward toward the interior, but deeper ones leveled off and sloped downward in the inner ria.

The tidally-averaged flow on 26 June was directed inward in the layers below the thermocline in the middle and inner ria, but inflow was confined to deeper layers in the outer ria (Figure 12e and $\mathrm{f})$. The core of strongest inward flow $\left(>10 \mathrm{~cm} \mathrm{~s}^{-1}\right)$ occurred at mid-depths in the middle ria near $8.76^{\circ} \mathrm{W}$, as also seen at A4 in Figure 9. Lower layer convergence was 
present in the inner ria consistent with vertical transport from the deep inflow lower to a shallow outflow above $7 \mathrm{~m}$ depth. In most of the ria there was essentially zero transverse flow except near the southern entrance where strong $\left(>20 \mathrm{~cm} \mathrm{~s}^{-1}\right)$ flow above $25 \mathrm{~m}$ depth crossed the ria from the north, as seen at the outer moorings (Figure 11).

The average of 20 Minibat traverses of Line 3, just outside the middle ria, over a semi-diurnal cycle on 27 June (Figure 13) contains additional data from 9 CTD casts, ship underway sampling at $2.5 \mathrm{~m}$ depth and mooring sites A2 and A3. The lowest salinity was found above $10 \mathrm{~m}$ on the southern side of the ria. The inward component of currents was mainly similar to that observed a day earlier (Figure 12), with a maximum of inflow at $\sim 12 \mathrm{~m}$ beneath the strong thermocline and halocline sloping slightly upward to the north. As the first available bin of ship ADCP data was at $8 \mathrm{~m}$, near-surface outflow was not sampled except at the lateral moorings. However, outflow occurred on the northern side of the ria at all depths, consistent with the slope of the isotherms. Transports, calculated as before, were similar to during downwelling (but reversed), with $2.3 \times 10^{3} \mathrm{~m}^{3} \mathrm{~s}^{-1}$ inward and $1.0 \times 10^{3} \mathrm{~m}^{3} \mathrm{~s}^{-1}$ outward. The latter is an underestimate because constant velocity is assumed above the first measured bin. Errors in the inflow are smaller because velocity near bed was weak. Assuming overall zero net transport, mean outward velocity in the unsampled surface layer would be $12.9 \mathrm{~cm} \mathrm{~s}^{-1}$, which seems reasonable. Cross-ria flow (not shown) was northwestward and strongest at the thermocline depth.

Similar temperature and salinity structure is seen in the Arao section for Line 2, middle ria, on the same day (Figure 13). In this case, the section is an average of six transects of 5 CTD stations over a period of $8 \mathrm{~h}$. Surface salinities were lower than on Line 3 further out, 
consistent with greater river influence towards the interior. Bottom temperature and salinity similar to those on Line 3 traced the inward penetration of the oceanic upwelled water. Detided profiles of along-ria currents at A4 in the deep channel of Line 2 (Figure 13f) reveal that on 27 June the lower layer was inflowing with maximum speed at $10 \mathrm{~m}$ depth, just below the pycnocline, similar to the situation seen over the deep channel of Line 3. The strongest inflow took place one day earlier, and later profiles show a transition through essentially null flow to outflow on 1 July coincident with wind relaxation. No appreciable cross-ria flow was present at this point in the narrower, middle ria.

On 28 June, Mytilus sampled the along-ria Line $7 \mathrm{~b}$ while Arao made repeated transects across mooring A1 on Line 1 over the tidal cycle (Figure 14). Comparison with the along-ria section two days earlier (Figure 12) reveals an upward displacement of $\sim 5 \mathrm{~m}$ of the isotherms and isohalines, a cooling of surface waters by $1-2^{\circ} \mathrm{C}$ especially in the inner ria, and the disappearance of most of the low salinity surface layer. The mean Line 1 sections on 28 June showed that water as cool as $13.5^{\circ} \mathrm{C}$ with salinity $>35.6$ had penetrated along the seabed as far as A1 (Figure 15). A thin surface layer of fresher water across the width of the section indicated the continuing river influence. On 28 June, the along-ria flow at A1 was virtually null (Figure 15h), in contrast to the situation two days earlier when deep inflow and shallow outflow were evident. The weakening of the upwelling circulation on 28 June resulted in the warming and freshening seen in the Arao temperature and salinity time series at A1 (Figure $14 \mathrm{f}$ and $\mathrm{g})$.

Compared with Line 3 on 27 June, a weakened and smaller core of inflow centered at 11-12 m was present in the tidally averaged sections of 29 June (Figure 15). Outflow, more 
widespread, was evident in shallow layers at both coasts but again stronger on the northern side. Below $15 \mathrm{~m}$ currents were close to zero. Across ria flow (not shown) was generally northwestward, strongest in and above the thermocline. Inward transport was reduced to $1.7 \times 10^{3} \mathrm{~m}^{3} \mathrm{~s}^{-1}$ while outward transport was greater at $1.5 \times 10^{3} \mathrm{~m}^{3} \mathrm{~s}^{-1}$. Between 27 and 29 June, the complete disappearance of the low-salinity surface layer was accompanied by a slight surface warming, as well as a decrease of salinity and increase of temperature in the layers below $15 \mathrm{~m}$, due to vertical mixing. At the innermost Line 1 on 29 June, surface temperature had also increased, here by almost $1^{\circ} \mathrm{C}$, as the surface freshened slightly compared to the previous days (accumulated river outflow). De-tided current profiles at A1 in the centre of Line 1 (Figure 15f) show null current on 29 June throughout the measured column, prior to reversal of the upwelling circulation to shallow inflow and deep outflow on subsequent days. The warming and weak flows at A1 are consistent with the observed decreasing subsurface inflow on Line 3.

\section{Discussion}

\subsection{Outer ria}

During both upwelling and downwelling the outer ria (i.e., west of $8.81^{\circ} \mathrm{W}$ ) behaves essentially as a continuation of the circulation over the continental shelf. In both cases part of the prevalent flow of the shelf regime passes inside the Islas Cies to cross the ria. The tidal variations in the outer ria, largely semi-diurnal, have relatively small excursions so that variability is dominated by the synoptic scale changes. To compare circulation in the two cases, vertically averaged current maps were prepared for the layer between 7 and $13 \mathrm{~m}$, which incorporates the uppermost available bins from the ship ADCP. This depth range is 
located within the surface, inflowing layer during downwelling, but forms the uppermost stratum of the lower, inflowing layer during upwelling. Both maps are based on data taken over three days that include repeated transects and a survey of the entire ria when the circulation was strongly developed.

Under northward wind conditions, the through-flow forms a meander inside A5 (Figure 16a) as the coastally-trapped waters of the Western Iberian Buoyant Plume progress along the south coast before turning northward to cross the ria west of $8.81^{\circ} \mathrm{W}$, probably as a joint result of shoaling bathymetry, narrowing of the middle ria, and the pressure gradient related to set up in the inner ria. This cross-ria flow supplied the outflow along the northern shore but some continued inward. In the upper layer in the outer ria on $30 \mathrm{Sept}, 14.5 \times 10^{3} \mathrm{~m}^{3} \mathrm{~s}^{-1}$ entered across Line 5, while about $13.9 \times 10^{3} \mathrm{~m}^{3} \mathrm{~s}^{-1}$ exited across the same line. These transports compare to $13.3 \times 10^{3} \mathrm{~m}^{3} \mathrm{~s}^{-1}$ leaving through the north mouth (Table 2). The differences are probably insignificant given the large uncertainties related to the extrapolations near surface and shore. They are consistent, however, and an order of magnitude larger than the transports in the middle and inner ria.

During equatorward wind events, as in June 2007, a continuation of the coastal upwelling jet flows directly southward across the outer ria (Figures 11 and 16b). This flow introduces over the northern sill waters upwelled onto the continental shelf outside the ria. At the same time, denser waters intrude along the deeper seabed of the southern mouth below this southward wind-driven flow. The coolest water crossing the northern sill at $25 \mathrm{~m}$ depth and that entering at $\sim 40 \mathrm{~m}$ along the southern channel had essentially the same TS signature $(<12.6 \mathrm{C}, 35.7)$. Transport estimates from ship ADCP indicate an inflow from the north 
around $11.0 \times 10^{3} \mathrm{~m}^{3} \mathrm{~s}^{-1}$, but this is likely an underestimate because of the faster unsampled surface layer.

In both scenarios, northward recirculation was seen within the outer ria. During downwelling, the main inflow meandered cyclonically through the area, centered around site A5, while during upwelling, a cyclonic eddy to the inside of the southward jet was indicated (Figure 16). The wider, outer ria behaves in a way similar to open bays in upwelling areas, like Monterey Bay (Rosenfeld et al., 1994; Graham and Largier, 1997; Shulman et al., 2010), Antofagasta Bay (Piñones et al., 2007), False Bay (Grundlingh and Largier, 1990) or Todos Santos Bay (Perez-Brunius, personal communication). Recent HF radar observations of surface flow in the outer ria reveal complex flow patterns as wind-driven shelf flows interact with the ria topography (Piedracoba, personal communication), while Lagrangian Coherent Stucture analysis of numerical modelling work suggests that details of the surface flow are controlled by capes (Huhn et al., 2012).

\subsection{Middle and Inner Ria}

In the middle/inner ria, lateral circulation is weak due to the narrowness of the basin, but the channel is deep enough to allow vertically sheared flows that are strongest after the onset of upwelling or downwelling winds over the shelf. Density-driven circulation in the mid/inner ria resembles estuarine circulation during upwelling conditions and inverse estuarine circulation during downwelling conditions. During onset of downwelling, the density of ria waters may be comparable with, or even lower than, that of incoming ocean waters because of the estuarine influence and warming of the interior ria. e.g. on 26 September, the middle 
ria was $\sim 0.1 \mathrm{~kg} \mathrm{~m}^{-3}$ less dense than water in the southern mouth. Even so, surface layer flow into the ria is observed during subsequent strengthening of southwesterly winds, counter to the density-related pressure gradient. Gradually rising sea level at Vigo during this period is consistent with relaxation of the surface depression accumulated over the upwelling season in the interior. As soon as Western Iberian Plume Water reaches the ria, salinity of the incoming water decreases progressively and the upper layer density difference reverses between mouth and middle ria. Salinity and density of the middle ria decrease more slowly by dilution and replacement. However, the inner ria receives enough river input that the middle ria remains higher in salinity and density than either outer or inner, as in Figure 8. .The shallow inflow above $15 \mathrm{~m}$ introduces the low salinity waters entering through the southern mouth into the mid/inner ria (Figures 8 and 16a). These zones therefore experience a transient flushing event over a few days, with outflow through the northern mouth and at depth, followed by a slowly varying quasi-steady state and gradual accumulation of freshwater in the interior if the winds and coastal ocean density remain constant.

At the start of upwelling, the density of ocean water is greater than that of ria water (e.g. by $\sim 0.5 \mathrm{~kg} \mathrm{~m}^{-3}$ on $18 \mathrm{June}$ ), but this contrast is rapidly reduced because freshwater runoff and surface heating in the mid/inner ria are insufficient to balance loss of buoyancy through the density-driven exchange flow. Initially wind, sea surface slope and density contrast act together to advect light surface waters out of the ria. Though the upper ouflowing layer is too shallow to be detected by the moored and shipboard current profilers, the compensating inflow just below the velocity interface is seen clearly in the middle and inner ria in Figures 12 and 16b. In the outer ria and southern mouth the inflow occurs at deeper levels beneath the through-flow and ascends along the central channel to the middle-ria. Again, a several-day 
transient flushing event takes place to transform the hydrographic properties of the entire ria to a cooler, saltier, denser condition.

Prolonged downwelling homogenises the outer and middle ria, but acts counter to the estuarine circulation and traps freshwater runoff in the inner ria. Prolonged upwelling acts in the same sense as the estuarine circulation and stratifies the ria by introducing dense water along the bottom, raising the interface and flushing low-salinity, warm water out in a thin surface layer. In both upwelling and downwelling situations, ocean-derived changes in temperature intrude as far as A1 in the inner ria (Figures 3 and 10). During these transitions to upwelling or downwelling, the effects of diurnally varying local surface wind stress and tidal motions on sub-tidal exchange are not well known but they appear to be secondary. However, during rare periods of persistent upwelling or downwelling, when ria-ocean density gradients are weak, one may expect tidal and wind effects within the ria to be relatively more important.

In the time series of winds, sea level, currents and water properties, wind-correlated, but pressure-gradient-driven, intrusion of sub-surface dense water into the mid/inner ria is evident during upwelling (e.g., Figure 9) and surface low-density water intrudes during downwelling (e.g., Figure 3). During both experiments, currents at A4 in depths below 15 $\mathrm{m}$ are more correlated with sea level $(\mathrm{r}=0.6-0.7, \mathrm{p} \geq 99 \%)$ than with wind fluctuations $(\mathrm{r} \sim 0.4$ in Sept and 0.5-0.6 in June, $\mathrm{p}<97.5 \%$ ), suggesting the predominance of pressure-gradient forcing. Nearer surface, current-sea level correlations decreased as current-wind correlations increased, especially for the upwelling study ( $\mathrm{r} 00.7, \mathrm{p} \sim 99 \%)$, indicating that current variability above the thermocline was more wind related. As winds and sea level are 
relatively well correlated at zero lag ( $r \sim 0.5$, p 97.5\%) with each other, as well as with current, the different dynamical effects are hard to distinguish.

The vertically sheared circulation that develops in the mid/inner ria in response to upwelling or downwelling over the shelf must incorporate vertical transport between the two layers to satisfy continuity. Vertical mixing is likely weak where stratification is very strong, as in the middle ria during transitions to upwelling or downwelling conditions. However in the shallower inner ria east of A1, bottom tidal stress and surface wind stress can be expected to bring about vertical mixing. During times of weaker stratification prior to or following intrusion events, significant vertical mixing is expected throughout the ria.

The flow in the lower layer at moorings A1 and A4 may be used to estimate the horizontal flux convergence between the sites and thus obtain an estimate of vertical transport (Table 2). Total flux was calculated as the sum of transports in each observed bin, assuming a parabolic lateral profile in along-ria velocity and zero velocity at the shoreline. The lower layer transports are generally much smaller than the in- or outflows seen on Line 3, because the latter include the general horizontal re-circulation in the outer ria as well as the vertical exchanges of the interior. Before 27 September 2006, the transport was similar at the two moorings and little net flux convergence. After that date, the lower layer transport became increasingly divergent, indicative of a downward flux of water between middle and inner ria coincident with the onset of warming. In 2007, the de-tided velocities in the lower layer varied similarly at both sites over the intensive period 25-29 June, implying flux convergence because of the greater cross-sectional area at A4. In both cases, the estimated divergence/convergence corresponds to vertical flux of water on the order $1000 \mathrm{~m}^{3} \mathrm{~s}^{-1}$ 
through an interface area of area $18.4 \times 10^{6} \mathrm{~m}^{2}$, and vertical velocities of $\sim 5 \mathrm{~m} \mathrm{day}^{-1}$ (or $\sim 0.5$ $\mathrm{x} 10^{-4} \mathrm{~m} \mathrm{~s}^{-1}$ ). These velocities are comparable with upwelling on the local open coast and are corroborated by observed vertical displacement rates of isopycnals between repeat hydrographic surveys in the inner ria.

Direct wind forcing extends far into the ria, because downwelling winds are typically from the southwest and so blow unrestricted along its length. Even under equatorward, upwelling conditions the topography of the surrounding coastal hills appears not to impede a general southward wind blowing (with an outward component) across the ria. Hence, although the variability within the ria follows that of the external wind, it is likely that local direct wind forcing, including diurnal forcing, also plays a role, as found by Bermúdez et al. (2013) in the nearby Ría de Arousa, but secondary to the inertia and pressure-gradient terms associated with the shelf flow interacting with topography.

The mid/inner ria behaves in a way more comparable with long semi-enclosed bays and fjords in upwelling regions, like Tomales Bay (Largier et al., in preparation), or Saldanha Bay (Monteiro and Largier, 1999), but is quite different from the tidal pumping regimes of San Diego Bay (Chadwick and Largier, 2012) and Bahía de San Quintín (Álvarez-Borrego and Álvarez-Borrego, 1982; Aveytua-Alcázar et al., 2008). Apart from their role in vertical mixing, it appears that tides play a minor role in longitudinal exchange in the middle ria where tidal excursions are order $5 \mathrm{~km}$ or less (compared with excursions of $20 \mathrm{~km}$ or more associated with slower but more persistent density driven flows). Tidal excursions and flow energy are likely to be dominant in the innermost ria. 


\section{Summary}

Observations in the Ria de Vigo in September 2006 and June 2007 confirm previous ideas about bulk exchange. They also allow a new, more detailed view of circulation, stratification and water mass exchange in this ria that also informs more generally on bays in upwelling regions. Changes in wind forcing that lead to strong and persistent upwelling or downwelling events over the shelf result in flushing of the wider, outer ria by through-flow of shelf currents and flushing of the mid/inner ria by wind forcing and density-driven exchange. Transports in the outer ria are an order of magnitude greater than the overturning transports of middle and inner ria.

Under downwelling conditions outflowing water that has been subducted or downwelled in the central and inner ria clearly is evacuated from the ria below about $15 \mathrm{~m}$. Most leaves through the deep southern channel, but some presumably exits through the north mouth mixed into the general outflow there above the $25 \mathrm{~m}$ sill. In contrast, during upwelling estuarine and inner ria waters flow out as a thin $(<7 \mathrm{~m})$ surface layer exclusively via the southern mouth.

Thus there is a certain asymmetry between upwelling and downwelling conditions. In the former, the ria becomes strongly stratified, the through-flow crosses directly inside the islands, the inflow occurs along the seabed through both mouths, and the surface layer outflow takes place only through the southern mouth. In the latter, the ria tends to homogeneity, the through-flow is circuitous, the outflow takes place through both mouths, and inflow occurs in a relatively thick $(15 \mathrm{~m})$ surface layer only through the southern mouth. 
Upwelling conditions flush any river outflow from the interior quickly, fill it with upwelled Eastern North Atlantic Central Water and maintain the ria cool, while downwelling conditions introduce coastal Western Iberian Buoyant Plume water and allow retention and build up in the inner ria of fresher river outflow that is gradually heated by the sun. The existence of the northern, shallower mouth permits the through-flow, without which circulation of the ria would be more two-layer with less lateral variation.

The penetration of shelf waters far into the ria is important for supporting its productive ecosystem and mussel aquaculture industry. The exchange of waters between the ria and ocean delivers biogenic material, prevents the build-up of hypoxic conditions and also has a role in development of HABs. The flushing of the ria was observed in this study to have a largely transient nature yet the wind-driven events persist long enough to develop the shelf response and subsequent intrusion into the ria (order of 3 days). The peak transport rates observed in the middle ria $\left(\sim 2 \times 10^{3} \mathrm{~m}^{3} \mathrm{~s}^{-1}\right)$ lasted for only a day or two, and are therefore larger than the averaged transport rates calculated from spatially and temporally sparse box model surveys. This and other Rias are commercially very important for the European Mussel industry. If forecast of $\mathrm{HAB}$ events are to be achieved, then accurate meteorological forcing needs to be of sufficient temporal and spatial resolution to capture these rapidly evolving events.

\section{Acknowledgments}

Field project supported by Xunta de Galicia under project PDIGIT05RMA40201PR. Writing up was supported under Interreg-Poctep project 0313_RAIA_CO_I_E. Two Sontek ADPs 
were loaned by José María Cortéz of Sidmar SA and one Nortek ADP by Oswaldo López of Innova SA. One ADCP was loaned by the University of Vigo, courtesy of G. Rosón. Wind data sets were obtained from the Spanish national meteorological service, MeteoGalicia, and Puertos del Estado. Many colleagues at IIM supported and participated in field work and shared their knowledge of the ria. The captain and crew of Mytilus and Arao cheerfully provided their indispensable expertise in the field operations. 
References

Álvarez I., deCastro, M., Gómez-Gesteira, M., Prego, R. (2005) Inter- and intra-annual variability of the salinity and temperature evolution in the Galician RíasBaixas-ocean boundary (northwest Spain). Journal of Geophysical Research: Oceans, 110, C04008, doi:10.1029/2004JC002504.

Álvarez-Borrego, J., Álvarez-Borrego, S. (1982) Temporal and spatial variability of temperature in two coastal lagoons. CalCOFI Reports XXIII, 188-197.

Aveytua-Alcázar, L., Camacho-Ibar, V.F., Souza, A.J., Allen, J.I., Torres, R. (2008)

Modelling Zostera marina and Ulva spp. in a coastal lagoon. Ecological Modelling, 218, 354-366, doi:10.1016/j.ecolmodel.2008.07.019.

Bermúdez, M., Pietrzak, J.D., Cea, L., Puertas, J., Stelling, G.S., de Boer, G.J. (2013) A numerical study of mixing and stratification dynamics in the ría de Arousa estuary (NW Spain) during summer. Coastal Dynamics, 161-172.

Blanton, J. O., Atkinson, L. P., Fernández de Castillejo, F., Lavin, A.(1984) Coastal upwelling off Rías Bajas, Galicia, Northwest Spain I: Hydrographic studies. Rapp. P. v. Reun. Cons. int. Explor. Mer., 183, 79-90.

Blanton, J. O., Tenore, K. R., Castillejo, F., Atkinson, L. P., Schwing, F. B., Lavin, A.(1987) The relationship of upwelling to mussel production in the Rias on the western coast of Spain. J. Mar. Res., 452, 497-511.

Cerralbo, P., Grifoll, M., Espino, M., López, J. (2013) Predictability of currents on a mesotidal estuary (Ria de Vigo, NW Iberia). Ocean Dynamics, 63, 131-141 doi:10.1007/s10236-012-0586-9.

Chadwick, D.B and Largier, J. L. (1999) Tidal exchange at the bay-ocean boundary. Journal of Geophysical Research: Oceans, 104, C12, doi: 10.1029/1999JC900165.

F.G. Figueiras, F. G., Labarta, U., Fernandez Reiriz, M.J.(2002) Coastal upwelling, primary production and mussel growth in the Rías Baixas of Galicia. Hydrobiologia, 484, 121-131.

Firing, E., Bahr, F., Caldwell, P. , Ranada, J., Zhu, W. (1995) Processing ADCP Data with the CODAS Software System. Version 3.1., JIMAR, University of Hawaii, 1000 Pope Road, Honolulu, Hawaii 96822.

Gilcoto, M., Álvarez Salgado, X. A., Pérez, F. F. (2001), Computing optimum estuarine residual fluxes with a multiparameter inverse model method (OERFIM): Application to the Ría de Vigo (NW Spain). Journal of Geophysical Research: Oceans, 106, 31,303-31,318.

Gilcoto, M., Pardo, P. C., Álvarez-Salgado, X.A., Pérez, F. F. (2007) Exchange fluxes between the Ría de Vigo and the shelf: A bidirectional flow forced by remote wind. Journal of Geophysical Research: Oceans, 112, C06001, doi:10.1029/2005JC003140.

González Vilas, L., Spyrakos, E., Torres Palenzuela, J.M., Pazos, Y. (2014) Support Vector Machine-based method for predicting Pseudo-nitzschia spp. blooms in coastal waters (Galician rias, NW Spain). Progress in Oceanography, 124, 66-77, doi:10.1016/j.pocean.2014.03.003

Graham, W.M. and Largier, J.L. (1997) Upwelling shadows as nearshore retention sites: the example of northern Monterey Bay. Continental Shelf Research, 17, 509-532.

Grundlingh, M. L. and Largier, J. L. (1990) Physical oceanography in False Bay: a review. 
Transactions of the Royal Society of South Africa, 47(4/5), 387-400.

Huhn, F. von Kameke, A. Allen-Perkins, S. Montero, P. Venancio, A. and Pérez-Muñuzuri, V. ( 2012) Horizontal Lagrangian transport in a tidal-driven estuary - transport barriers attached to prominent coastal boundaries. Continental Shelf Research, 39-40, 1-13,.

doi:10.1016/j.csr.2012.03.005

Monteiro, P.M.S. and Largier, J.L. (1999) Thermal stratification in Saldanha Bay (South Africa) and subtidal, density-driven exchange with the coastal waters of the Benguela upwelling system. Coastal Estuarine and Shelf Science, 49(6), 877-890.

Mourinho, C. and Fraga, F. (1982) Hidrografía de la ría de Vigo.1976-1977. Influencia anormal del río Miño. Investigaciones Pesqueras, 46(3), 459-468.

Peliz, A., Rosa, T.L., Santos, A.M.P., Pissarra, J.L. (2002) Fronts, jets, and counter-flows in the Western Iberian upwelling system. Journal of Marine Systems, 35, Issues 1-2, pp61-77, doi.:10.1016/S0924-7963(02)00076-3.

Piedracoba, S., Älvarez-Salgado, X.A., Rosón, G. and Herrera, J.L. (2005) Short-timescale thermohaline variability and residual circulation in the central segment of the coastal upwelling system of the Ría de Vigo (northwest Spain) during four contrasting periods. Journal of Geophysical Research: Oceans, 110, doi:10.1029/2004JC002556.

Pinoñes, A., Castilla, J. C., Guinez, R., Largier, J. L. (2007) Nearshore surface temperatures in Antofagasta Bay (Chile) and adjacent upwelling centers. Ciencias Marinas, 33(1):37-48.

Prego, R., and Fraga, F. (1992) A simple model to calculate the residual flows in a Spanish ría. Hydrographic consequences in the ría of Vigo. Estuarine Coastal Shelf Science, 34, 603615.

Romera-Castillo, C., Nieto-Cid, M., Castro, C.G., Marrasé1, C., Largier, J.L., Barton, E.D., Álvarez-Salgado, X.A.(2011) Fluorescence: absorbance ratio - tracing photochemical and microbial degradation processes affecting coloured dissolved organic matter in a coastal system. Marine Chemistry, 125, 26-38.

Rosenfeld, L.K., Schwing, F. B., Garfield, N., Tracy, D.E. (1994) Bifurcated flow from an upwelling center: a cold water source for Monterey Bay. Continental Shelf Research, 14, 9, 931-964.

Santos, A.M.P., Peliz, A., Dubert, J., Oliveira, P.B., Angélico, M. M., Ré, P. (2004) Impact of a winter upwelling event on the distribution and transport of sardine (Sardina pilchardus) eggs and larvae off western Iberia: a retention mechanism. Continental Shelf Research, 24, 2, 149-165, doi: 10.1016/j.csr.2003.10.004.

Seeyave, S., Probyn, T., Figueiras, F.G. Álvarez-Salgado, X. A., Barton, E.D., Lucas, M., Purdie, D. (2013) Nitrogen uptake of phytoplankton assemblages under contrasting upwelling and downwelling conditions in the coastal embayment of the Ría de Vigo, NW Spain. Estuarine, Coastal and Shelf Science, doi: 10.1016/j.ecss.2013.03.004

Shulman, I., Anderson, S., Rowley, C., DeRada, S., Doyle, J., Ramp, S. (2010) Comparisons of upwelling and relaxation events in the Monterey Bay area. Journal of Geophysical Research: Oceans, 115, C6, doi: 10.1029/2009JC005483

Souto, C., Gilcoto, M., Fariña-Busto L. and Fiz. F. Pérez (2003) Modeling the residual circulation of a coastal embayment affected by wind-driven upwelling: Circulation of the Ría de Vigo (NW Spain). Journal of Geophysical Research: Oceans, 108, C11, doi: 
Taboada, J.J., Prego, R., Ruiz-Villarreal, M., Gómez-Gesteira, M., Montero, P., Santos, A.P.,. Pérez-Villar, V. (1998) Evaluation of the seasonal variations in the residual pattern of the Ria of Vigo (NW Spain) by means of a 3D baroclinic model. Estuarine, Coastal and Shelf Science, 47 (1998), pp. 661-670.

Torres López, S., Varela, R.A., Delhez, E. (2001) Residual circulation and thermohaline distribution of the Ría de Vigo: a 3-D hydrodynamical model. Sci. Mar., 65 (Suppl. 1): 277289. 


\section{Figures}

Figure 1. Bathymetry of Ria de Vigo with isobaths at $10 \mathrm{~m}$ intervals, ADCPs A1-A8 (orange dots are ADCP only, blue dots are ADCP + hydrographic sensors), thermistor moorings T1-T7 (small blue dots), meteorological stations M1-M3 (green dots), tide gauge (red dot) and transects 1-7 (blue lines) sampled repeatedly during the intensive experiments. Thermistor moorings and ADCP A8 were deployed during CRIA2 only. Meteorology station M3 is located off map at the position indicated, $10 \mathrm{~km}$ offshore. Inset shows location of study area. Outer, middle and inner zones are demarcated by the vertical lines.

Figure 2. (a) Meridional component of wind speed at the offshore Silleiro mooring September-October 2006; light and heavy lines represent hourly data and low pass filtered values, respectively; (b) purple line shows port of Vigo de-tided, atmospherically adjusted sea level, while blue line indicates bottom temperature at A4 in middle ria; (c) along-ria component of de-tided current velocity at A4; inward flow is positive. The green shading marks the duration of the intensive field work.

Figure 3. Time series of (a) atmospherically corrected de-tided sea level in port of Vigo and northward component of wind (light line is hourly averages, heavy line is low-pass filtered) off Cabo Silleiro; (b) temperatures at sites throughout the ria; (c) $2 \mathrm{~m}$ and $20 \mathrm{~m}$ salinity from sites A2 and A3 and $3 \mathrm{~m}$ salinity at A1; (d) temperature at indicated depths from site A2. The green shading and labels indicate the timing of lines surveyed and shown in subsequent figures.

Figure 4. Currents at (a) A6 in the northern mouth of the ria; outward component of flow is positive; (b) A7 in the southern mouth; inward component of flow is positive. The green shading and labels indicate the timing of lines surveyed and shown in subsequent figures.

Figure 5. Sections across Line 5, outer ria, for (left) 26 and (right) 30 Sept showing (a ,b) temperature, $(c, d)$ salinity, and $(e, f)$ along-ria velocity components. The position of mooring A5 is indicated in $(e, f)$.

Figure 6. Average over a semi-diurnal cycle of 28 occupations of Line 3 in the outer ria of (a) temperature, (b) salinity, (c) across-ria component of flow (positive toward $150^{\circ}$ ), and (d) along-ria component of flow (positive toward $60^{\circ}$ ) on 28 September.

Figure 7. Section along Line 7a between moorings A4 and A5 averaged over semi-diurnal cycle on 29 September of (a) temperature, (b) salinity, (c) across-ria and (f) along-ria velocity components. Green labels in (e) and (f) indicate ADCP mooring positions.

Figure 8. Distributions at $5 \mathrm{~m}$ depth of salinity on (a) 26 September and (b) 30 September 2006. Overlaid are de-tided current vectors at the mooring sites observed at mid-day nearsurface (5-7 m depth, red) and near-bottom (c. $5 \mathrm{~m}$ above bed, blue).

Figure 9. (a) Meridional component of wind speed at the offshore Silleiro mooring June-July 2007; light and heavy lines represent hourly data and low pass filtered values, respectively; (b) purple line shows port of Vigo de-tided, atmospherically adjusted sea level, blue line indicates bottom temperature at A4 in middle-ria; (c) along-ria component of de-tided current 
velocity at A4; inward flow is positive. The green shading marks the duration of the intensive field work.

Figure 10. Time series of (a) atmospherically corrected de-tided sea level in port of Vigo and northward component of wind (light line is hourly averages, heavy line is low-pass filtered) off Cabo Silleiro; (b) temperatures at sites throughout the ria; (c) $2 \mathrm{~m}$ and $20 \mathrm{~m}$ salinity from sites A2 and A3; (d) temperature at indicated depths from site A2. The green shading and labels indicate the timing of lines surveyed and shown in subsequent figures.

Figure 11. Currents at (a) A6 in the northern mouth of the ria; outward component of flow is positive; (b) A5 in the centre of the outer ria; northward flow is positive; (c) A7 in the southern mouth; inward component of flow is positive. The green shading and labels indicate the timing of lines surveyed and shown in subsequent figures.

Figure 12. Along-ria sections, Line 7b, made before (18 June, left, CTD stations) and after (26 June, right, Minibat) the onset of equatorward wind showing $(a, b)$ temperature, $(c, d)$ salinity, (e.f) components of ship ADCP velocity across-ria (toward $160^{\circ}$ ) and along-ria (toward $70^{\circ}$ ) on 26 June. Minibat and velocity sections are the averages of six transects over a semi-diurnal cycle. Bottom profile for 18 June is approximate for central channel, as some CTD stations were made in shallower water at the sides. Green labels indicate ADCP mooring positions.

Figure 13. Tidally averaged sections along (left) Line 3, outer ria, and (right) Line 2, middle ria, on 27 June of $(\mathrm{a}, \mathrm{b})$ temperature, (c,d) salinity, (e) inward component of flow, and (f) vertical profiles of de-tided inward velocity component at A4 in mid-channel of Line 2.

Figure 14. Sections on 28 June (Year Day 179) of (a) temperature on along-ria Line 7b, (b) tidally averaged temperature on Line 1, inner ria, (c) salinity on Line 7b, (d) tidally averaged salinity on Line 1, (e) vertical profiles of de-tided inward component of current at A1, and $(f, g)$ time variation of temperature and salinity over semi-diurnal cycle at A1. The arrows mark the intersection of the two lines and position of mooring A1.

Figure 15. Tidally averaged sections along (left) Line 3, outer ria, and (right) Line 1, inner ria, on 29 June of $(a, b)$ temperature, (c,d) salinity, (e) inward component of flow, and (f) vertical profiles of de-tided inward velocity component at A1 in mid-channel of Line 1.

Figure 16. Objective maps of currents in the depth range 7-13 $\mathrm{m}$ from ship ADCP observations for (a) 30 September 2006 and (b) 25-28 June 2007. In September, the depth range was entirely in the upper layer, whereas in June it was entirely in the lower. 
Table 1 Current profiler deployments during the two studies. Sites are indicated in Figure 1.

Sample interval refers to the effective ensemble average for the RDI profilers. Others averaged over 5 minutes every sample interval.

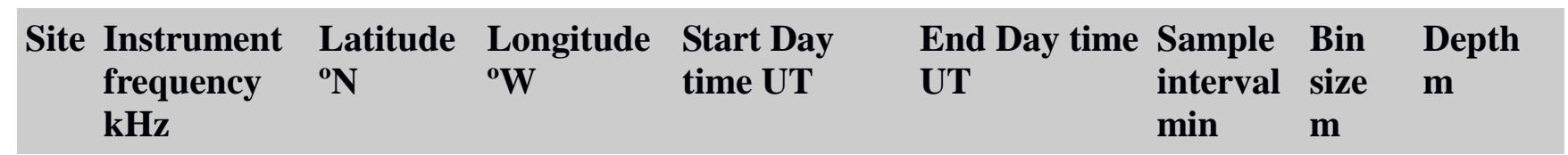

CRIA 1

$\begin{array}{lcccccccc}\text { A1 } & \text { RDI 1200 } & 42.2701 & 8.6942 & 20 / 09 / 061025 & 30 / 09 / 061900 & 1 & 1 & 21 \\ \text { A2 } & \text { RDI 1200 } & 42.2065 & 8.8101 & 25 / 09 / 061108 & 04 / 10 / 061030 & 1 & 1 & 20 \\ \text { A3 } & \text { RDI 1200 } & 42.2422 & 8.8301 & 25 / 09 / 061151 & 04 / 10 / 061155 & 1 & 1 & 18 \\ \text { A4 } & \text { RDI 600 } & 42.2397 & 8.7612 & 20 / 09 / 061122 & 16 / 10 / 061105 & 1 & 1 & 42 \\ \text { A5 } & \text { NorTek 600 } & 42.2161 & 8.8647 & 25 / 09 / 061229 & 27 / 10 / 061037 & 10 & 1 & 30 \\ \text { A6 } & \text { Aanderaa } & 42.2421 & 8.8844 & 25 / 09 / 061303 & 27 / 10 / 061230 & 10 & 4 & 26 \\ & \text { RCM!2 } & & & & & & & \\ \text { A7 } & \text { SonTek 600 } & 42.1814 & 8.8780 & 25 / 09 / 061156 & 19 / 12 / 061331 & 20 & 2 & 34\end{array}$

\section{CRIA 2}

$\begin{array}{lcccccccc}\text { A1 } & \text { RDI 1200 } & 42.2700 & 8.6933 & 18 / 06 / 070959 & 18 / 07 / 07 ~ 1800 & 1 & 0.5 & 20 \\ \text { A2 } & \text { RDI 1200 } & 42.2067 & 8.8100 & 15 / 06 / 07 ~ 1139 & 13 / 07 / 07 ~ 0818 & 1 & 1 & 20 \\ \text { A3 } & \text { RDI 1200 } & 42.2417 & 8.8283 & 15 / 06 / 070921 & 13 / 07 / 071230 & 1 & 1 & 17 \\ \text { A4 } & \text { RDI 600 } & 42.2400 & 8.7617 & 15 / 06 / 070829 & 18 / 07 / 070900 & 1 & 1 & 44 \\ \text { A5 } & \text { NorTek 600 } & 42.2167 & 8.8650 & 25 / 06 / 070857 & 28 / 07 / 071230 & 10 & 2 & 26 \\ \text { A6 } & \text { RDI 300 } & 42.2417 & 8.8850 & 21 / 06 / 070858 & 28 / 07 / 071341 & 1 & 1 & 26 \\ \text { A7 } & \text { SonTek 600 } & 42.1817 & 8.8783 & 25 / 06 / 071050 & 14 / 09 / 071028 & 10 & 1 & 34 \\ \text { A8 } & \text { SonTek 750 } & 42.1650 & 8.8633 & 25 / 06 / 070951 & 14 / 07 / 071157 & 10 & 3 & 32\end{array}$


Table 2. Transports $\mathrm{m}^{3} \mathrm{~s}^{-1}$. At moorings A1 and A4 transports are calculated assuming a lateral parabolic profile with zero velocity at the shore and are integrated over the bottom (lower) layer of contiguous in- or outflow. For the sections, they represent the integral of all in- or outflow over the transect.

\begin{tabular}{|c|c|c|c|c|c|c|}
\hline Date & & $\begin{array}{l}\text { A1 } \\
\text { Lower } \\
\text { Line1 }\end{array}$ & $\begin{array}{l}\text { A4 } \\
\text { Lower } \\
\text { Line2 }\end{array}$ & $\begin{array}{l}\text { A } 2 / 3 \\
\text { Line } 3\end{array}$ & $\begin{array}{l}\text { Outer ria } \\
\text { Line } 5\end{array}$ & $\begin{array}{l}\text { North mouth } \\
\text { Line } 6\end{array}$ \\
\hline $25 \mathrm{Sept}$ & In & $\begin{array}{c}138 \\
-\end{array}$ & $\begin{array}{c}173 \\
-\end{array}$ & & & \\
\hline $26 \mathrm{Sept}$ & In & $\begin{array}{c}514 \\
-\end{array}$ & $\begin{array}{c}498 \\
-\end{array}$ & & & 150 \\
\hline $27 \mathrm{Sept}$ & In & $\begin{array}{c}301 \\
-\end{array}$ & $\begin{array}{c}421 \\
-\end{array}$ & & & \\
\hline $28 \mathrm{Sept}$ & In & 247 & 434 & $\begin{array}{l}1287 \\
2661\end{array}$ & & \\
\hline $29 \mathrm{Sept}$ & In & $\begin{array}{c}- \\
231\end{array}$ & $\begin{array}{c}- \\
1224\end{array}$ & & & \\
\hline $30 \mathrm{Sept}$ & In & & $\begin{array}{l}- \\
1750\end{array}$ & & $\begin{array}{l}14478 \\
13948\end{array}$ & 13256 \\
\hline $1 \mathrm{Oct}$ & In & & $\begin{array}{c}- \\
2062\end{array}$ & & & \\
\hline
\end{tabular}

\begin{tabular}{|c|c|c|c|c|c|c|}
\hline Date & & $\begin{array}{l}\text { A1 } \\
\text { Lower } \\
\text { Line1 } \\
\end{array}$ & $\begin{array}{l}\text { A4 } \\
\text { Lower } \\
\text { Line2 } \\
\end{array}$ & $\begin{array}{l}\mathrm{A} 2 / 3 \\
\text { Line } 3 \\
\end{array}$ & $\begin{array}{l}\text { Outer ria } \\
\text { Line } 5 \\
\end{array}$ & $\begin{array}{l}\text { North mouth } \\
\text { Line } 6 \\
\end{array}$ \\
\hline 25 Jun & In & - & $\begin{array}{c}- \\
806\end{array}$ & & & \\
\hline 26 Jun & In & - & $\begin{array}{c}- \\
1853\end{array}$ & & & \\
\hline 27 Jun & In & $\begin{array}{c}- \\
591\end{array}$ & $\begin{array}{c}- \\
1170\end{array}$ & $\begin{array}{l}2280 \\
991\end{array}$ & & \\
\hline 28 Jun & In & $\begin{array}{c}- \\
89\end{array}$ & $\begin{array}{c}- \\
521\end{array}$ & & & 11050 \\
\hline 29 Jun & In & $\begin{array}{c}143 \\
-\end{array}$ & $\begin{array}{c}- \\
388\end{array}$ & $\begin{array}{l}1752 \\
1467\end{array}$ & & \\
\hline 30 Jun & In & $\begin{array}{r}43 \\
-\end{array}$ & $\begin{array}{c}183 \\
-\end{array}$ & & & \\
\hline $1 \mathrm{Jul}$ & In & $\begin{array}{c}- \\
254\end{array}$ & $\begin{array}{c}- \\
1229 \\
\end{array}$ & & & \\
\hline
\end{tabular}




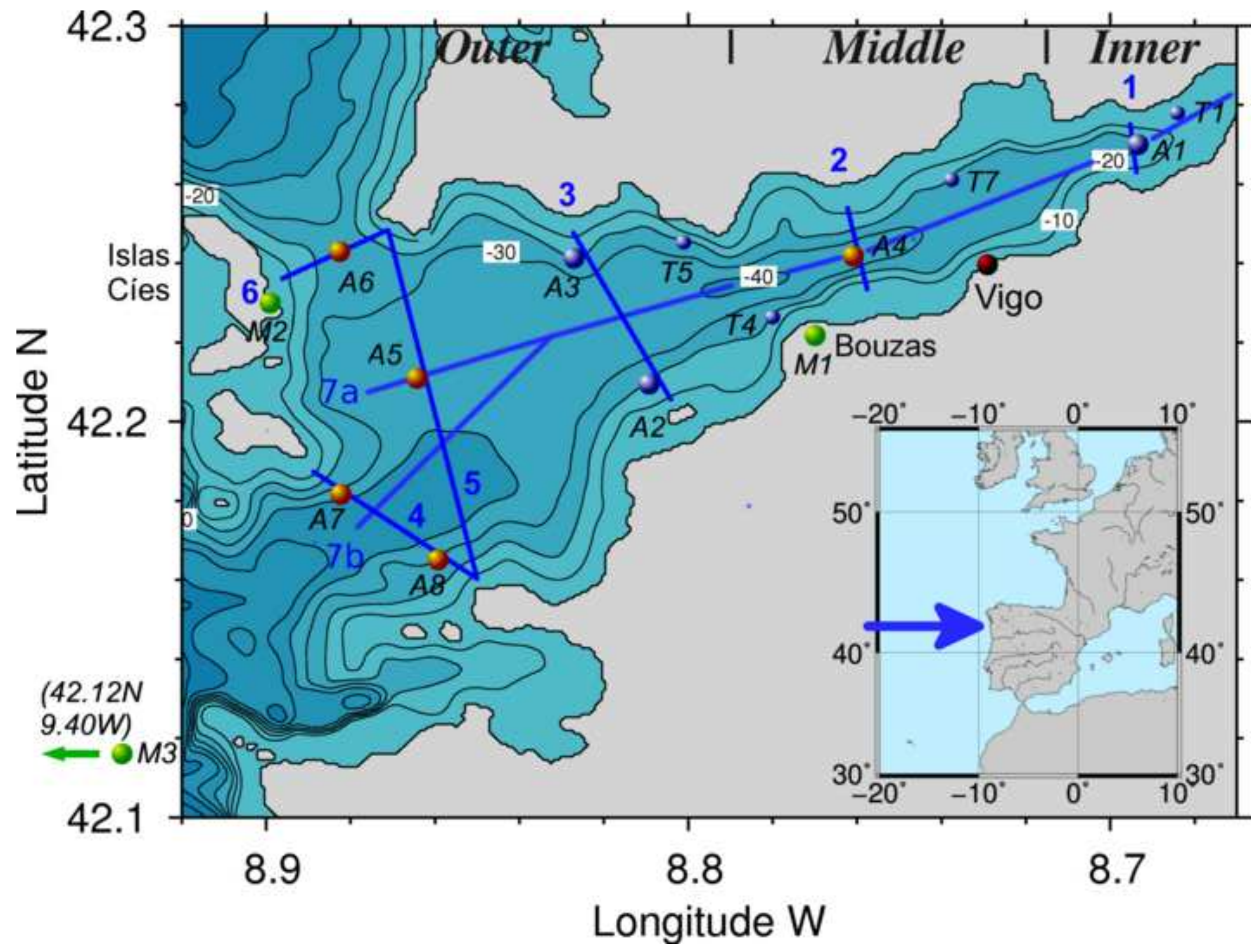



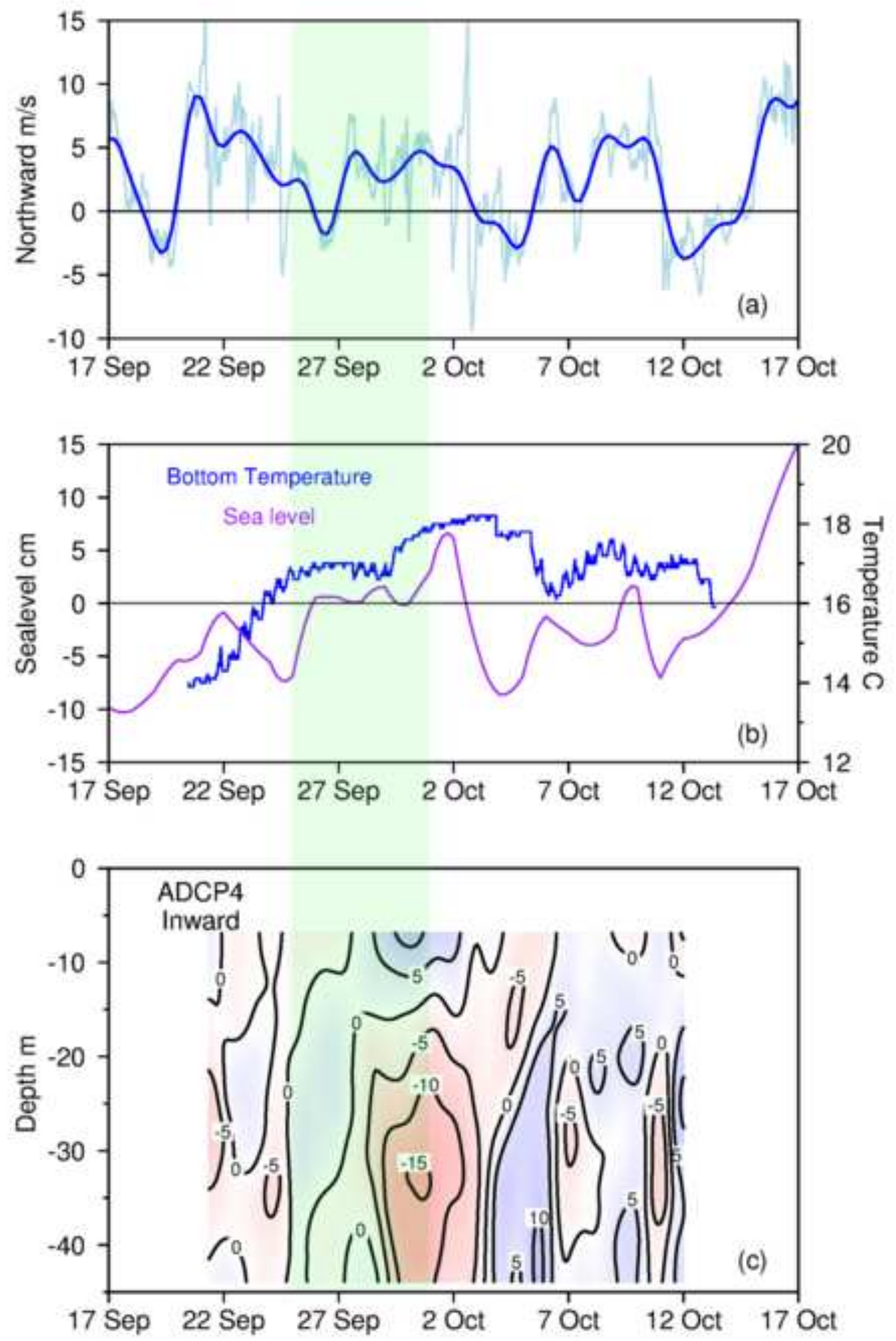

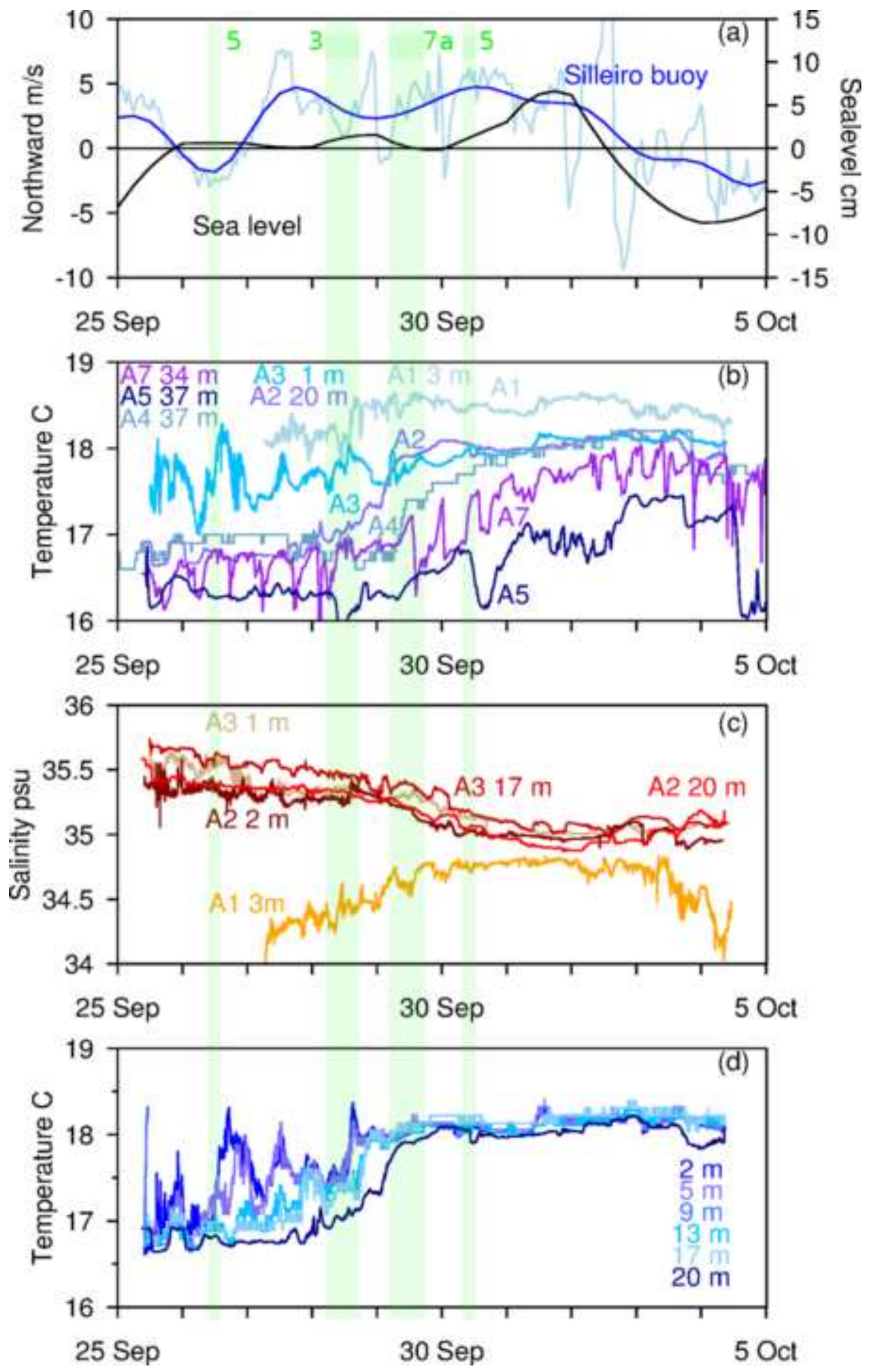

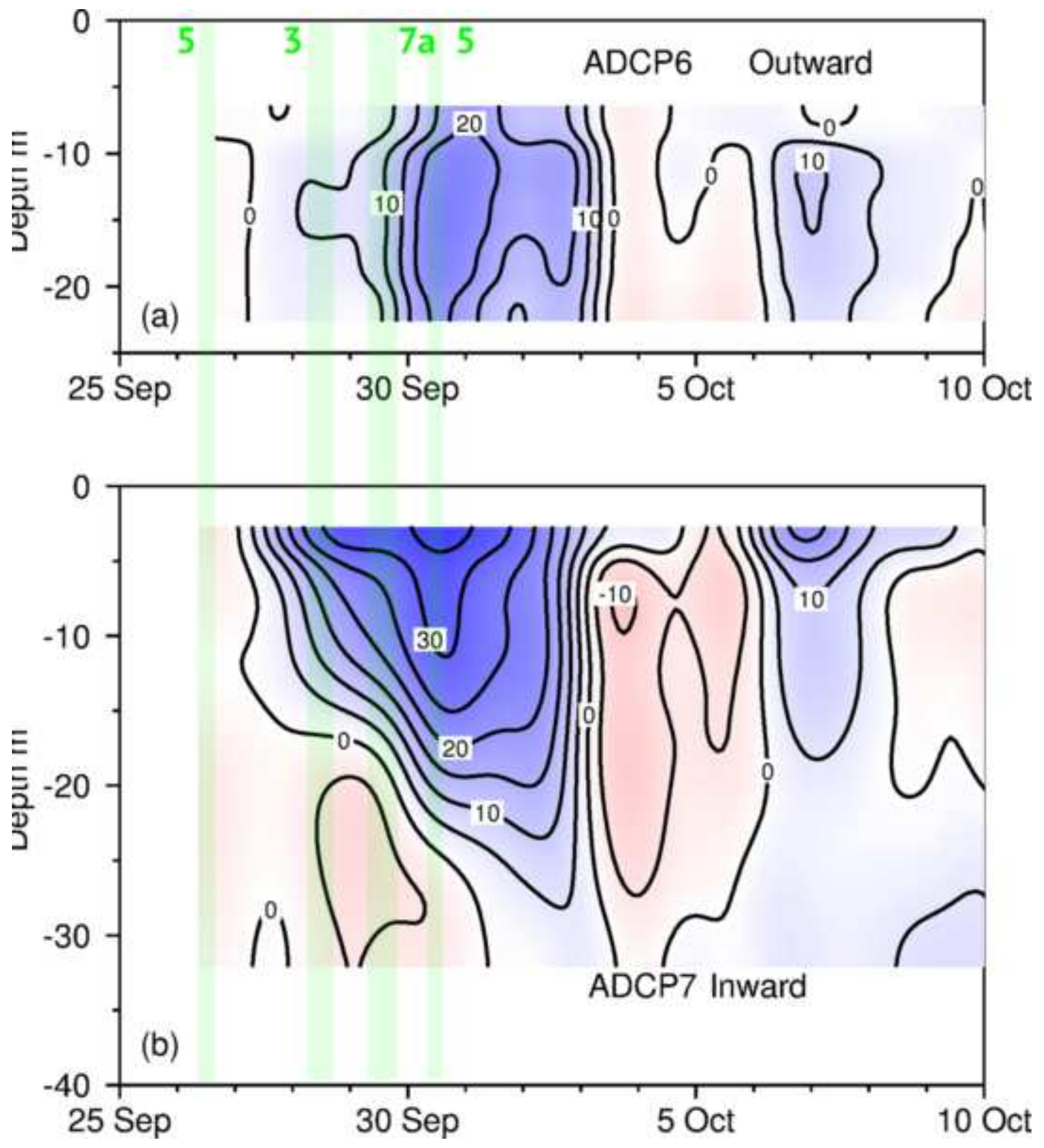

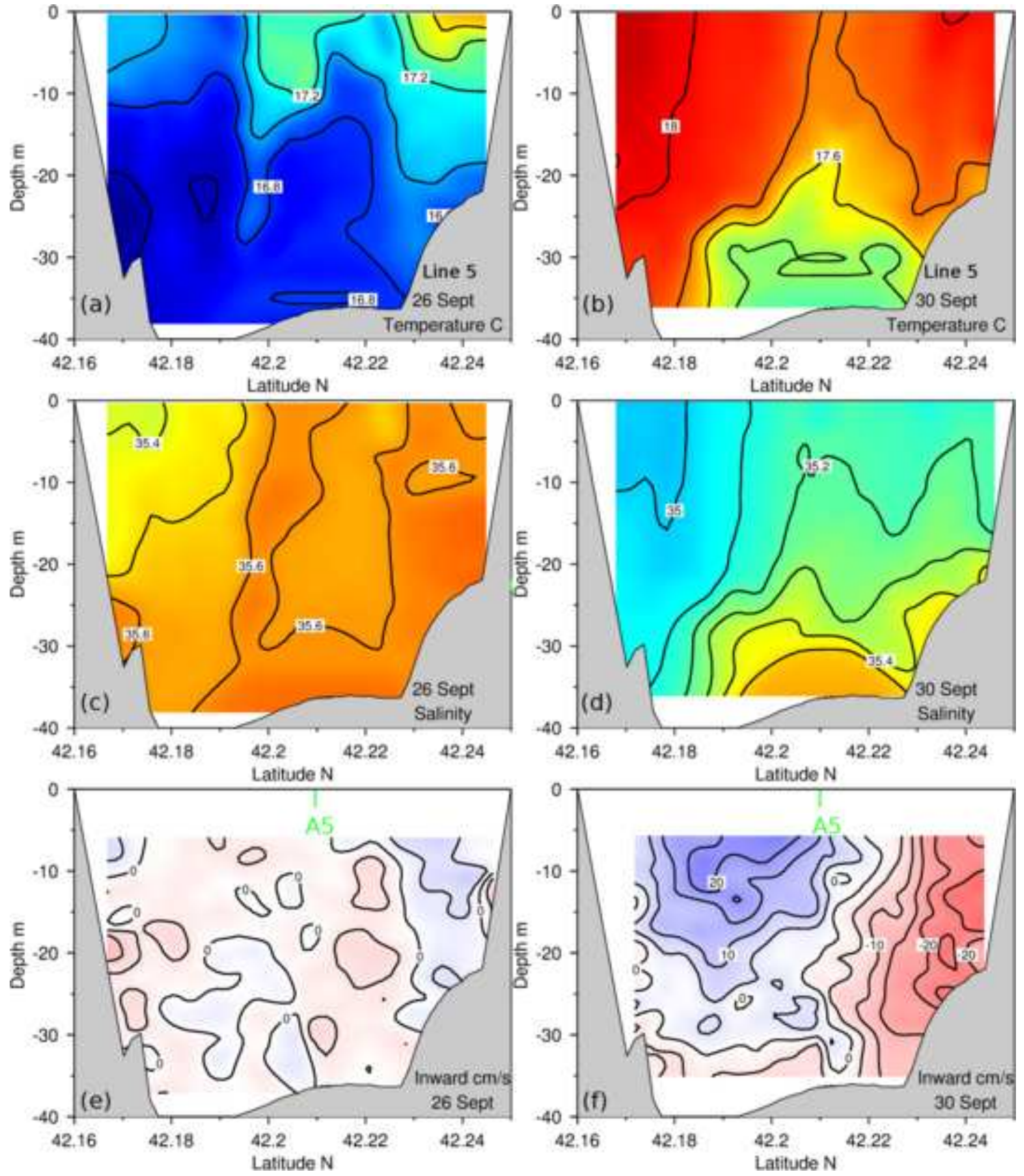

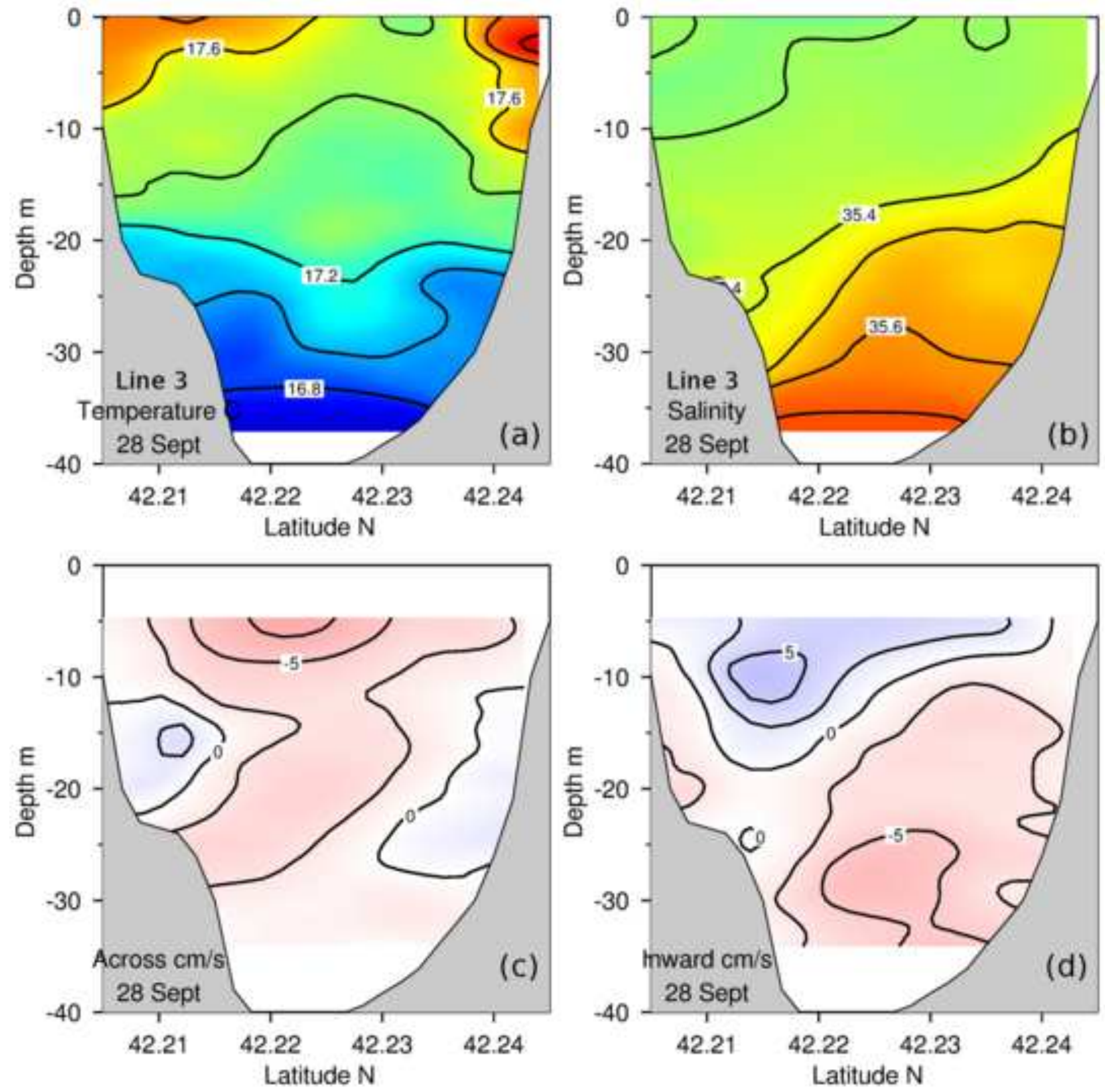

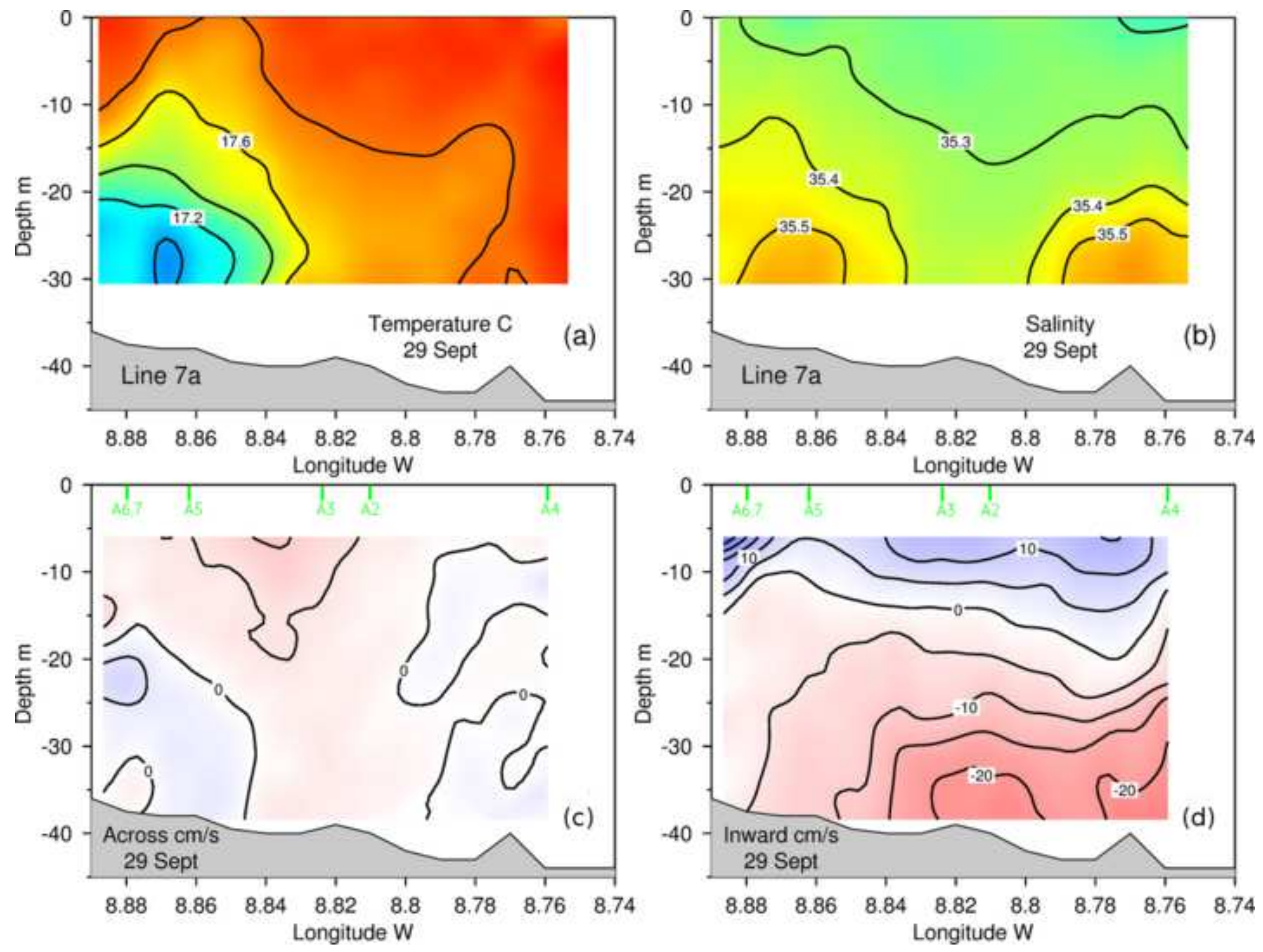


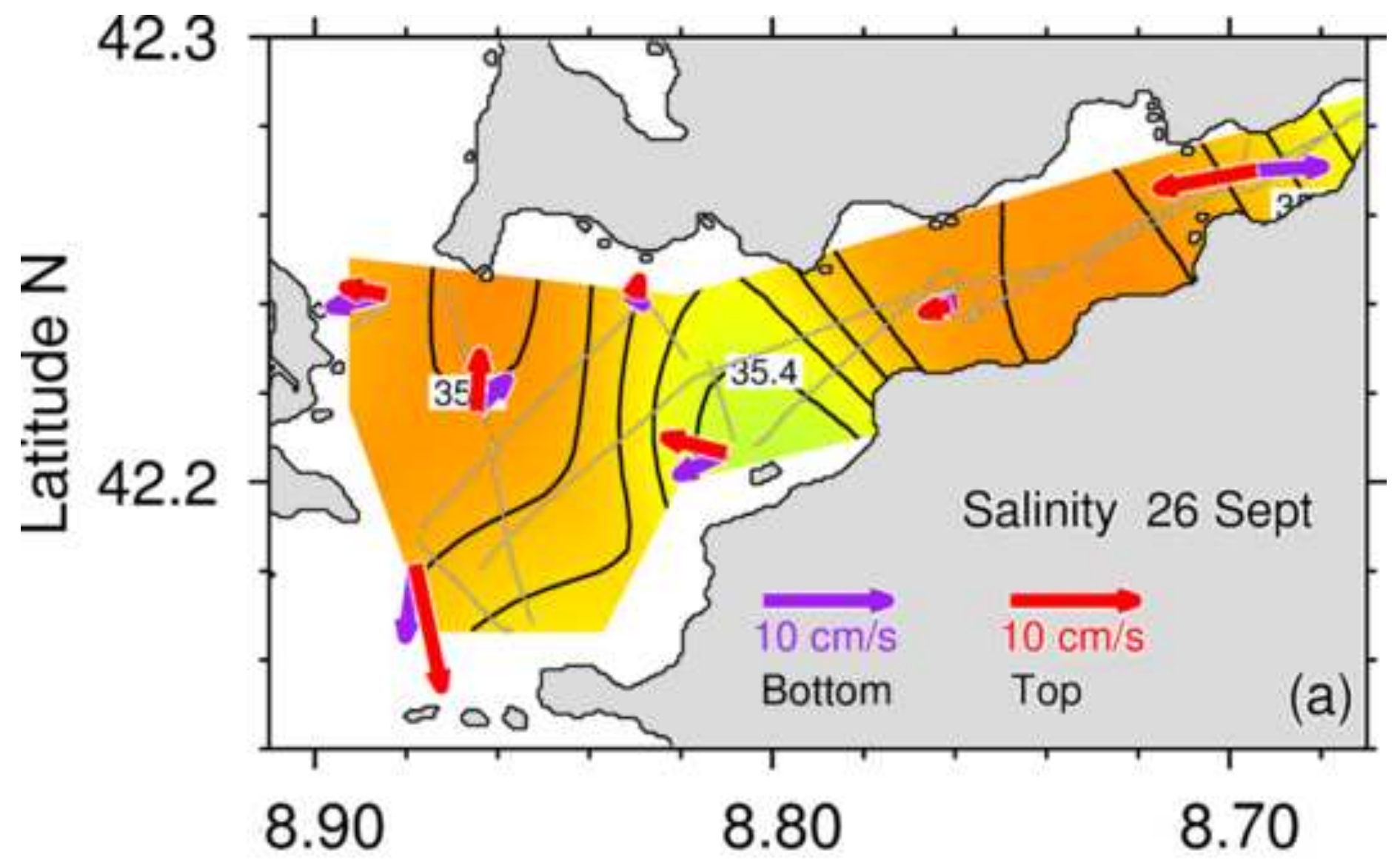

\section{Longitude W}

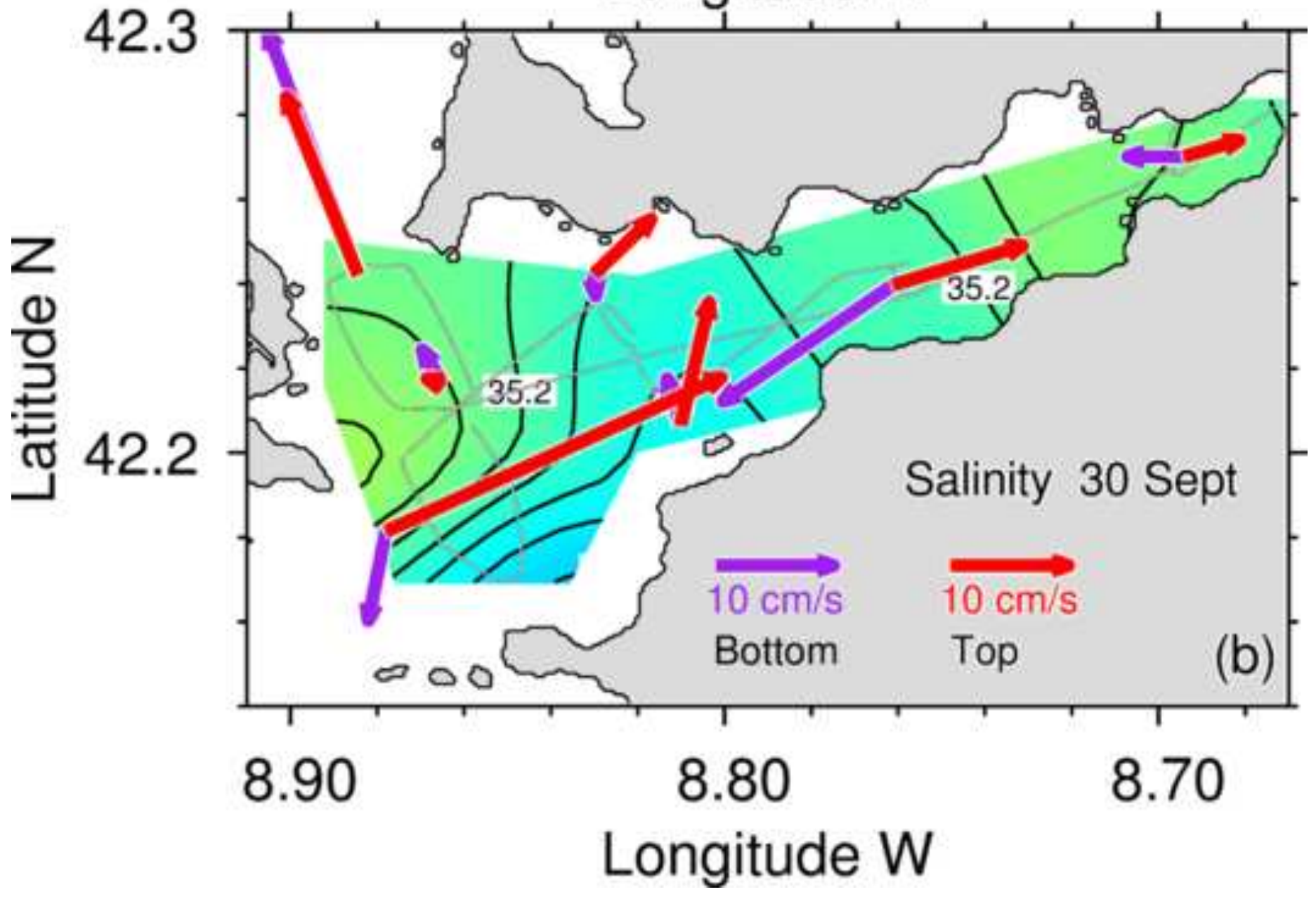



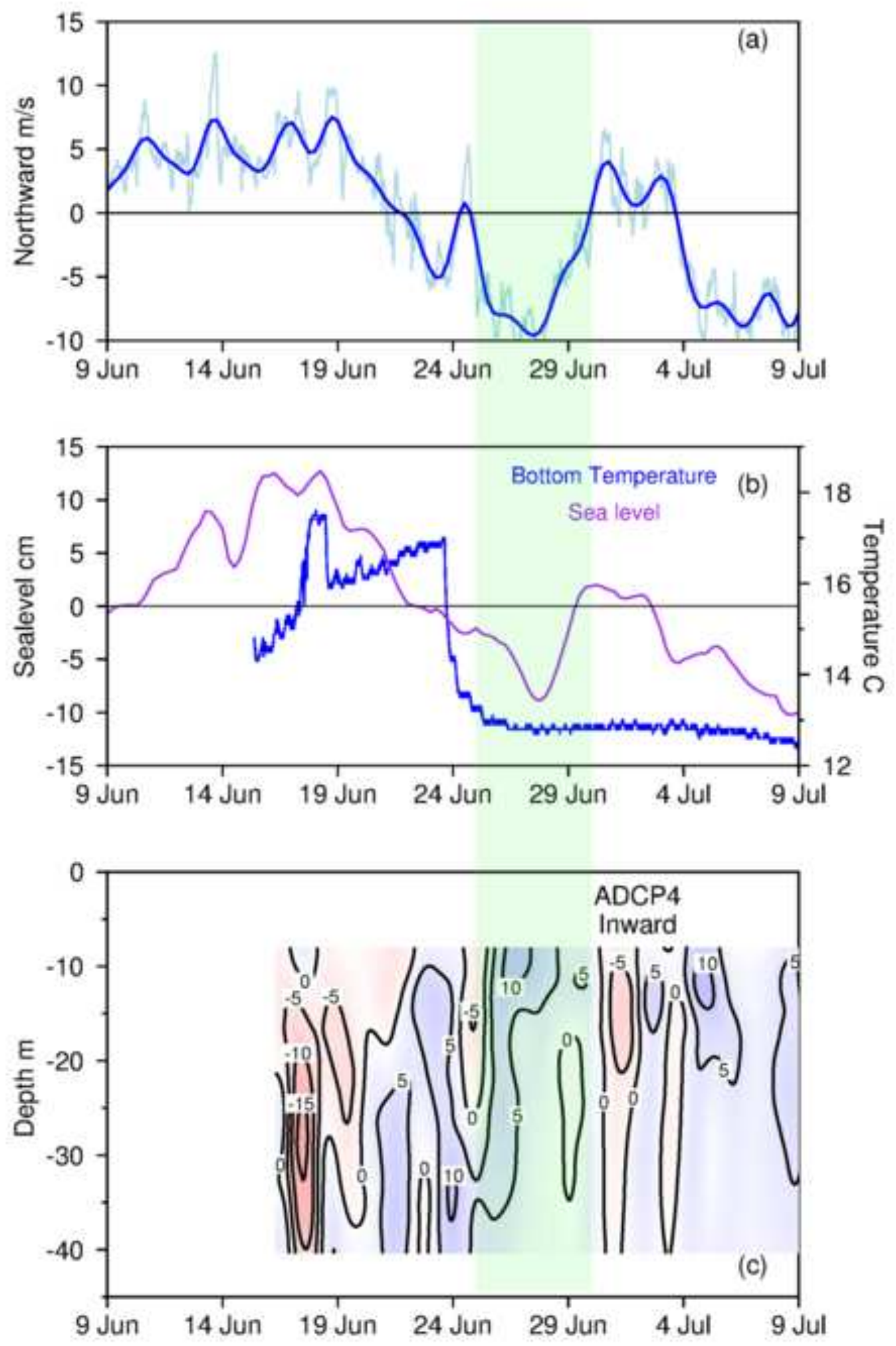

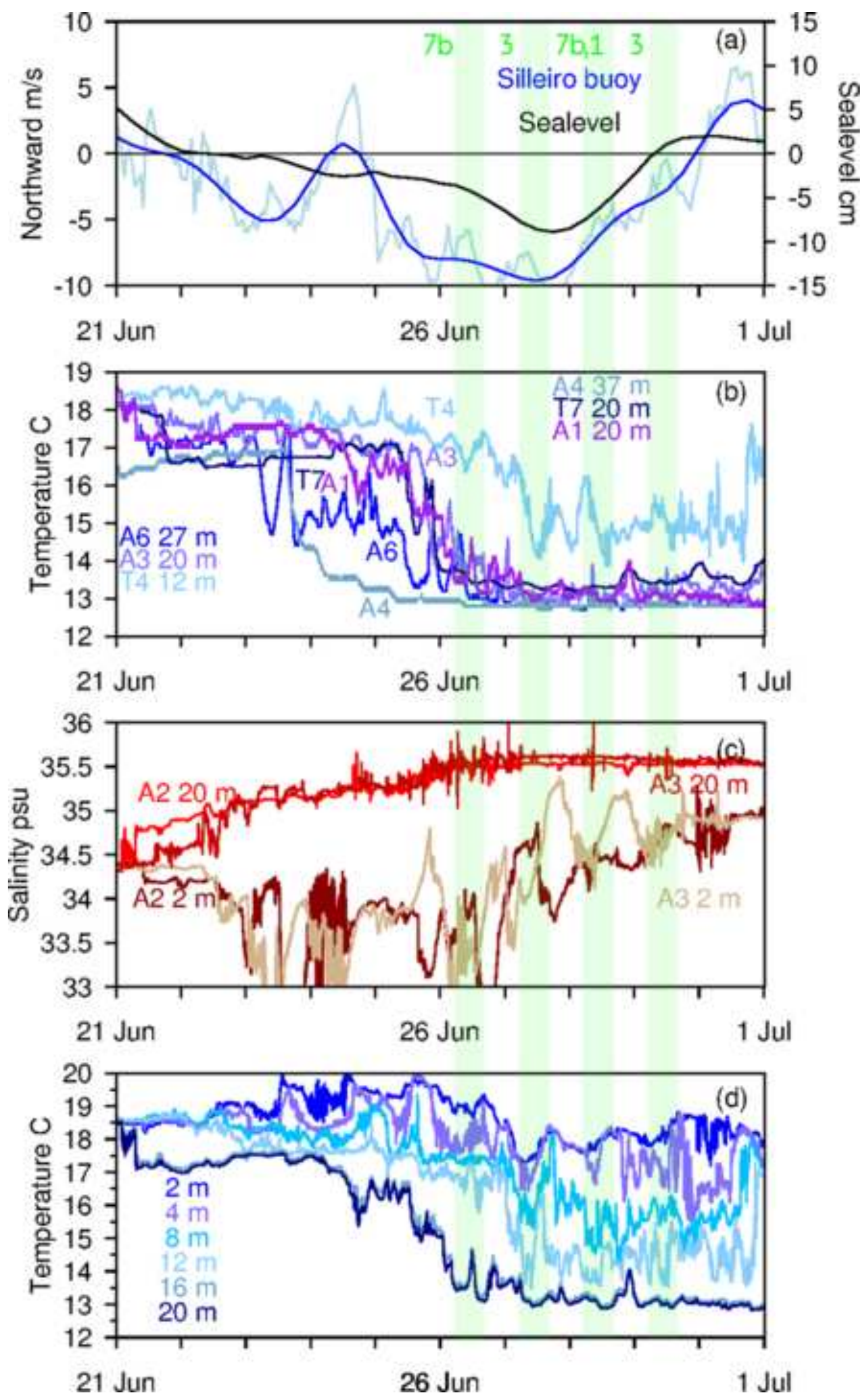
Click here to download high resolution image
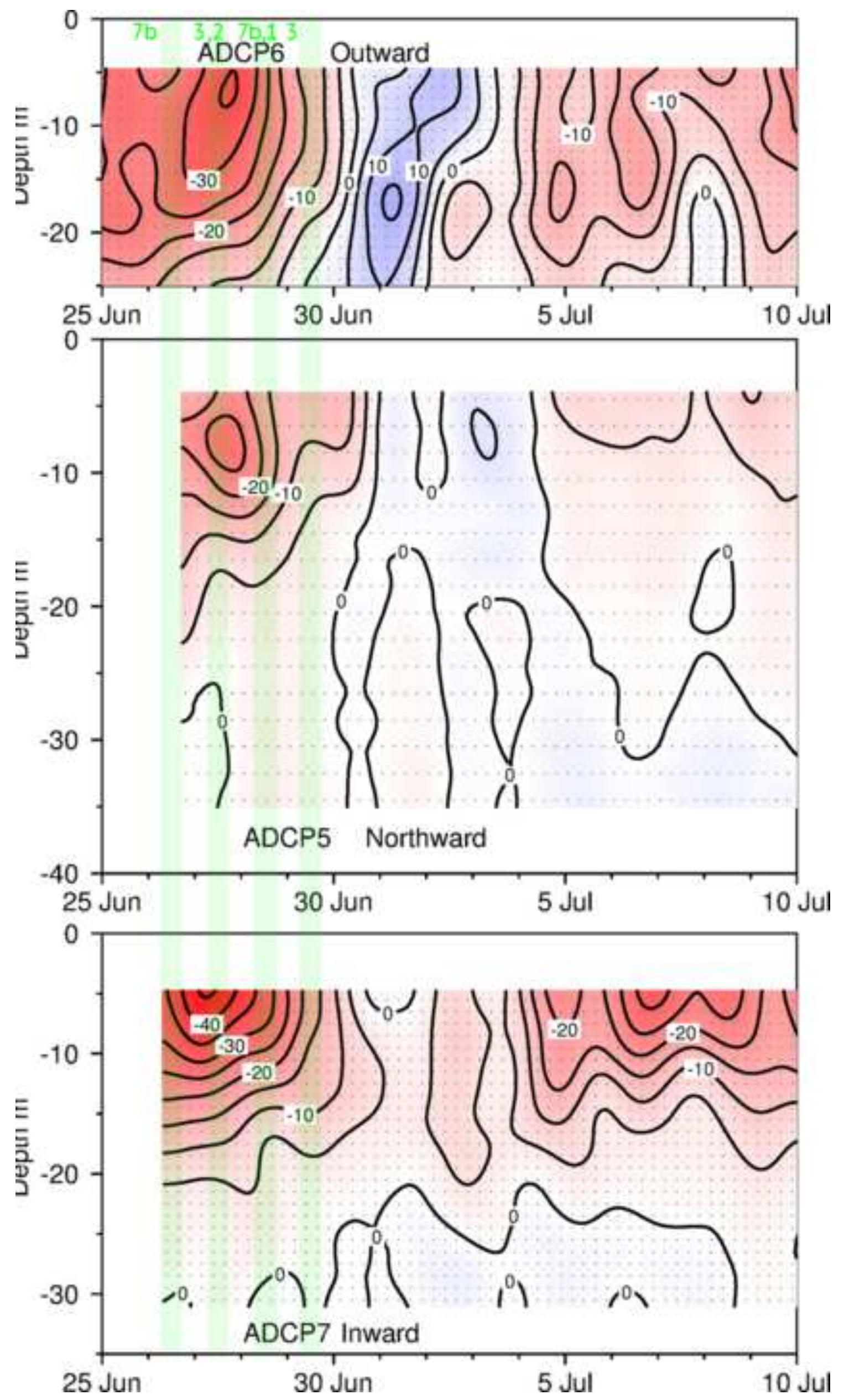

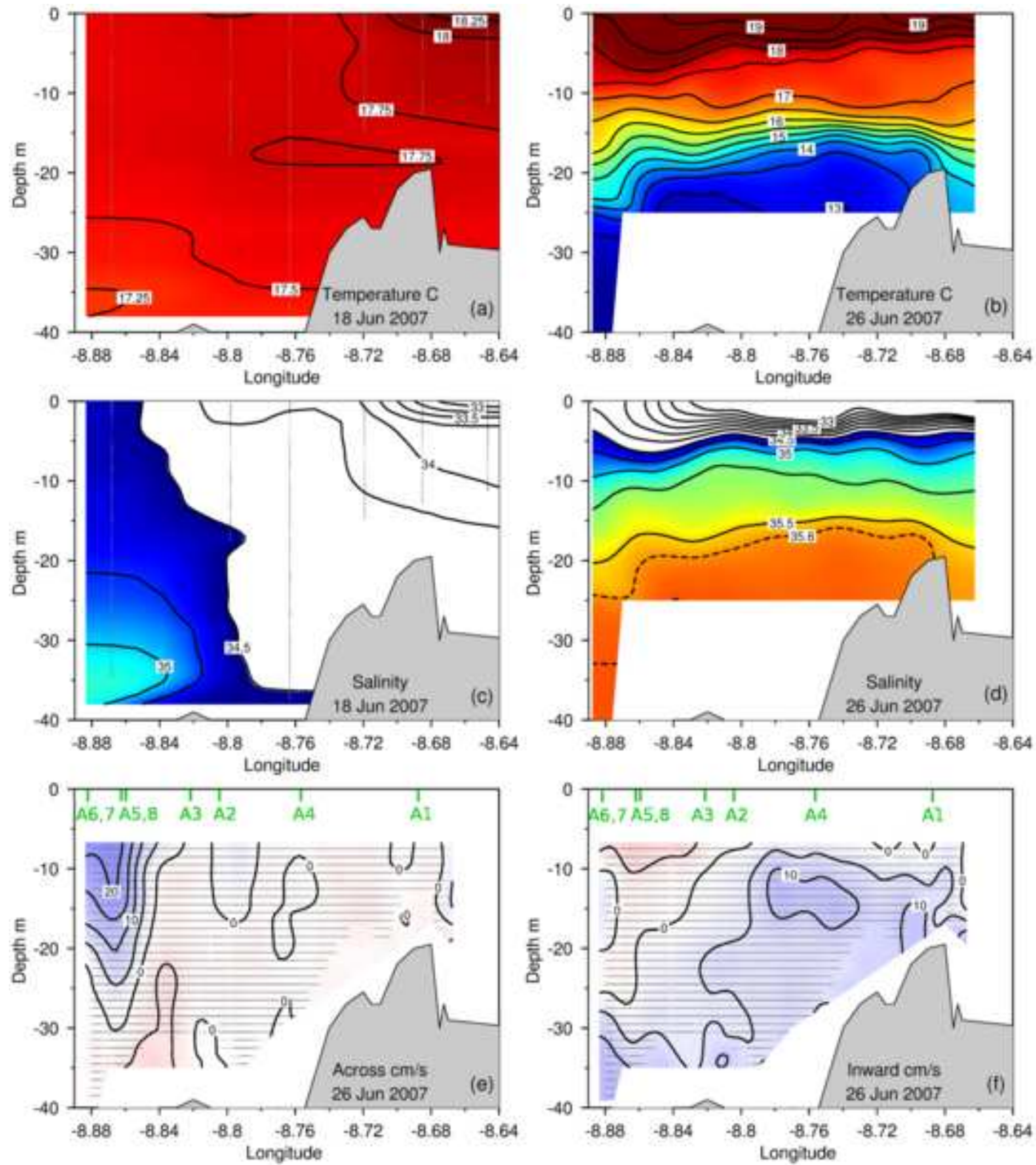

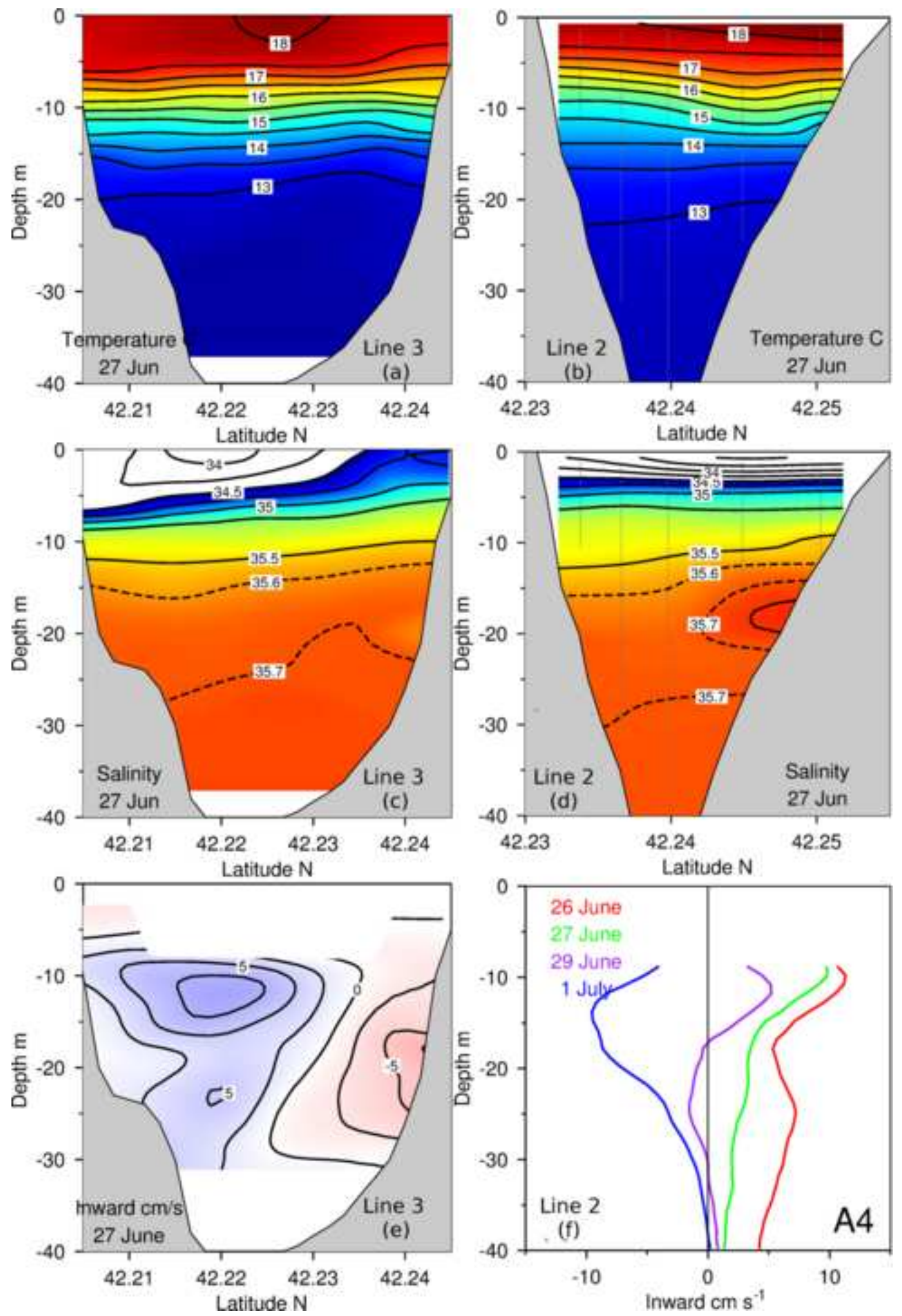
Figure 14

Click here to download high resolution image
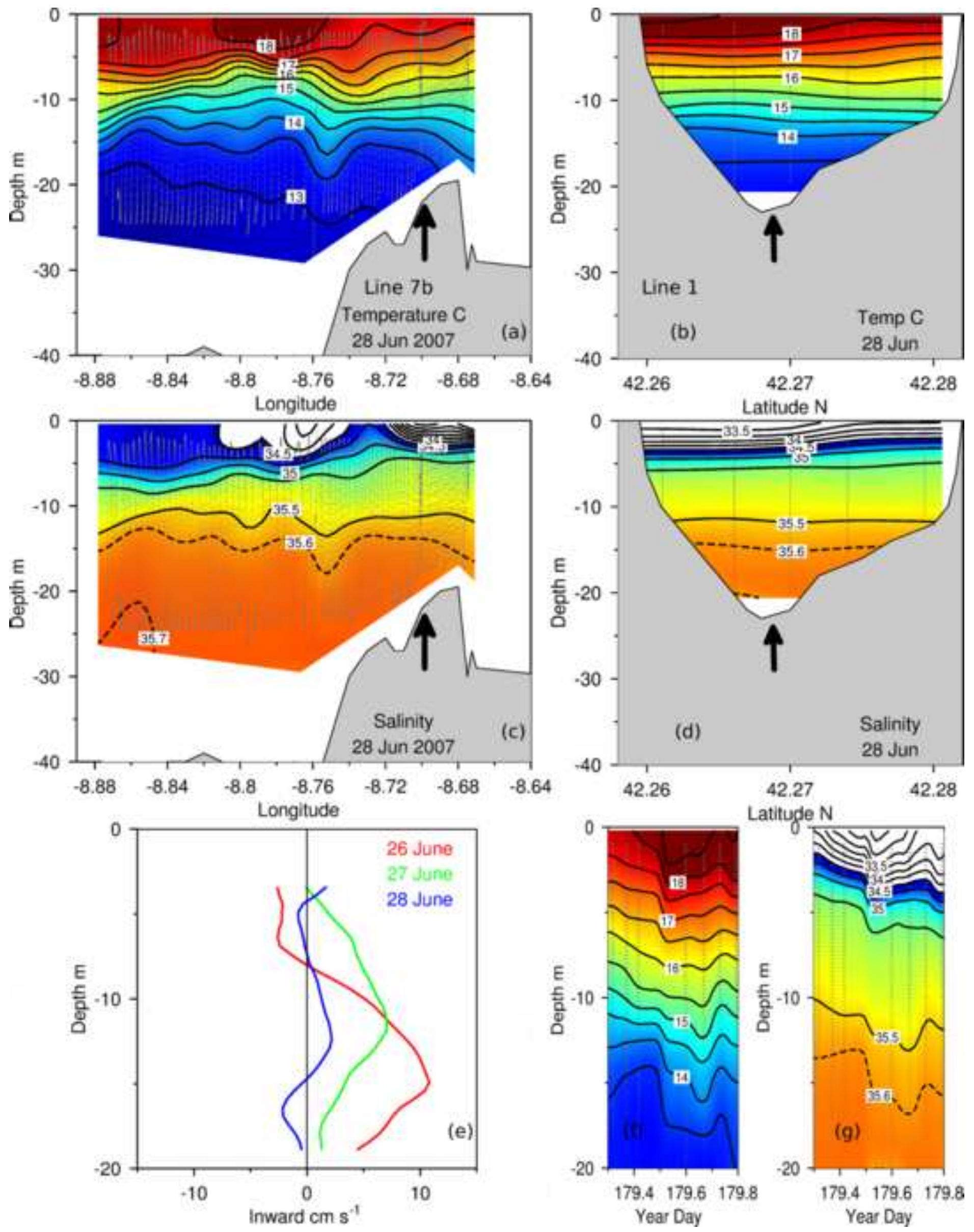
Click here to download high resolution image
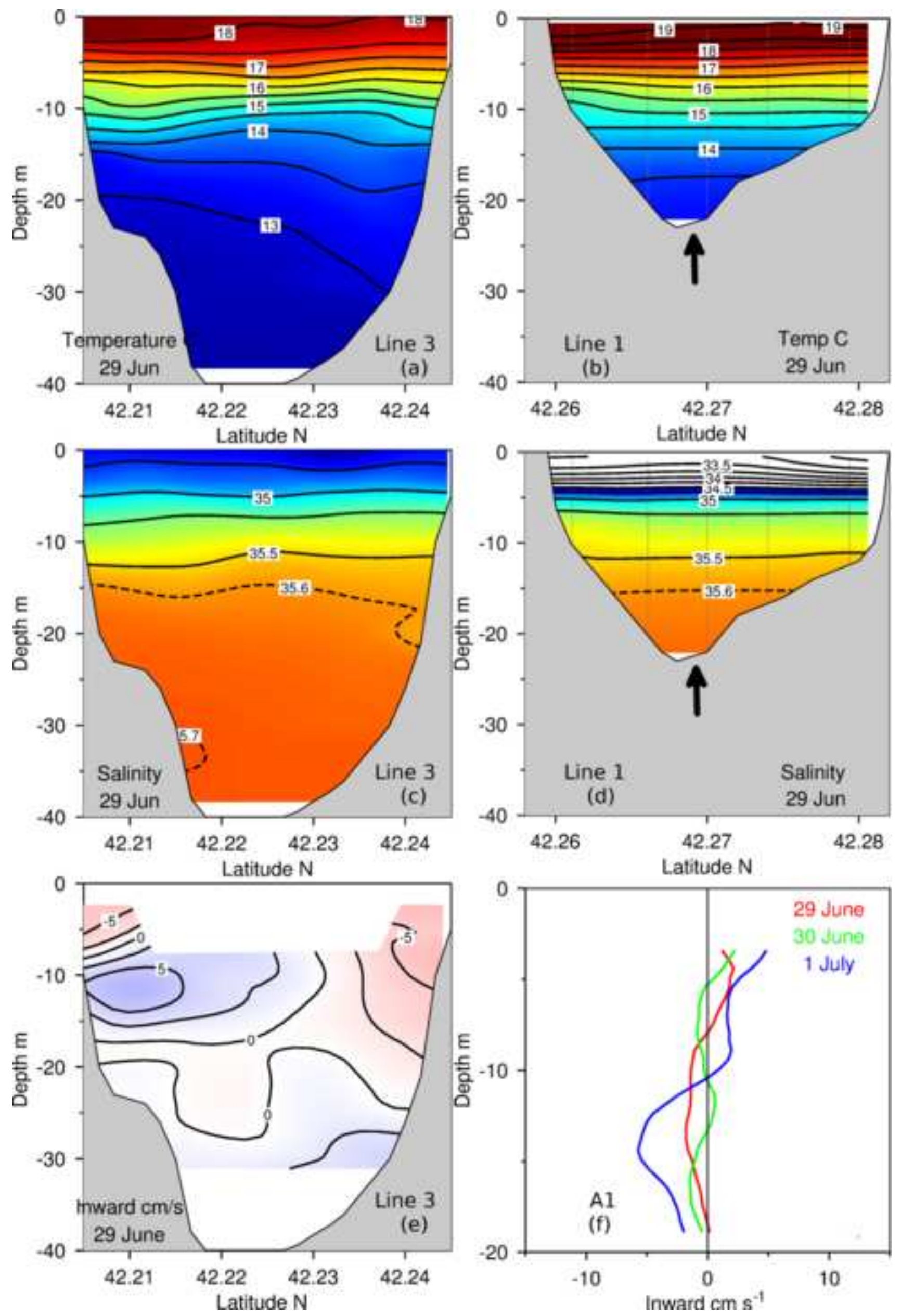


\section{Figure 16}

Click here to download high resolution image

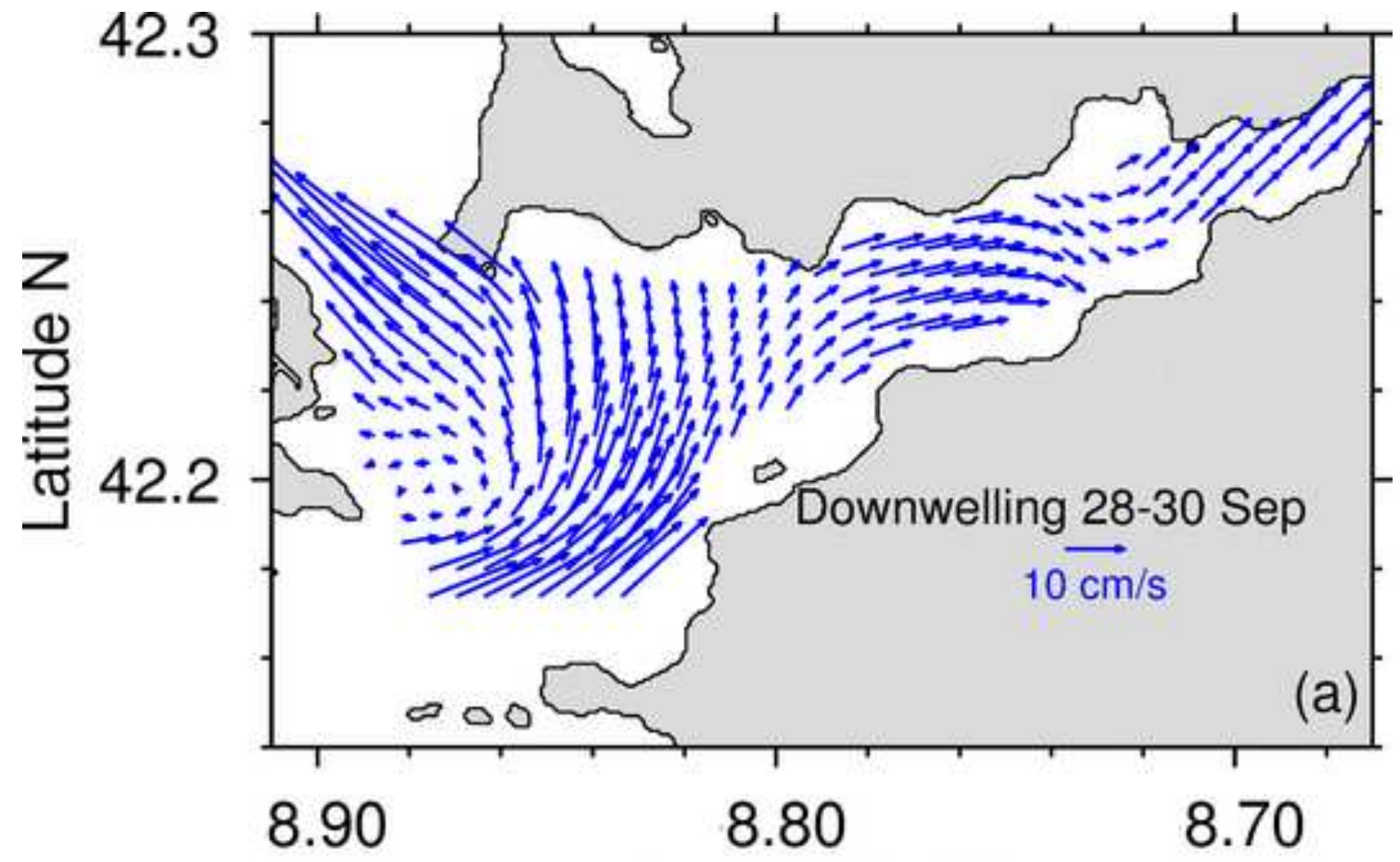

Longitude W

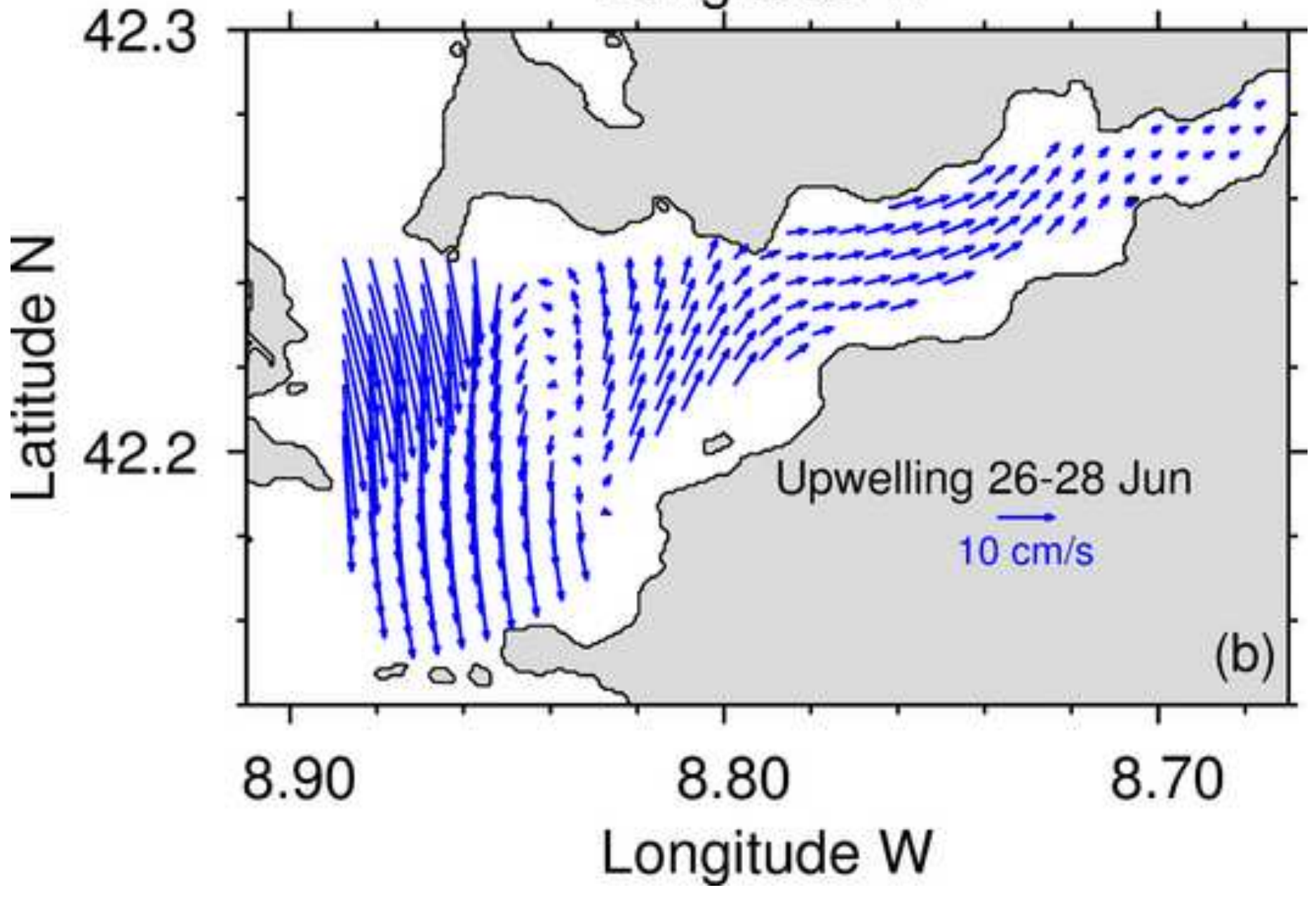

